\title{
Dissolved inorganic nitrogen in a tropical estuary in Malaysia: transport and transformation
}

\author{
Shan Jiang ${ }^{1}$, Moritz Müller ${ }^{2}$, Jie Jin ${ }^{1}$, Ying Wu ${ }^{1}$, Kun Zhu ${ }^{1}$, Guosen Zhang ${ }^{1}$, Aazani Mujahid ${ }^{3}$, Tim Rixen ${ }^{4}$, \\ Mohd Fakharuddin Muhamad ${ }^{3}$, Edwin Sien Aun Sia ${ }^{2}$, Faddrine Holt Ajon Jang ${ }^{2}$, and Jing Zhang ${ }^{1}$ \\ ${ }^{1}$ State Key Laboratory of Estuaries and Coastal Research, East China Normal University, 200062, Shanghai, China \\ ${ }^{2}$ Faculty of Engineering, Computing and Science Swinburne, University of Technology, Sarawak Campus, Malaysia \\ ${ }^{3}$ Faculty of Resource Science \& Technology, Universiti Malaysia Sarawak, 94300 Kota Samarahan, Sarawak, Malaysia \\ ${ }^{4}$ Leibniz Centre for Tropical Marine Research, Fahrenheitstr. 6, 28359 Bremen, Germany
}

Correspondence: Shan Jiang (sjiang@ @sklec.ecnu.edu.cn)

Received: 13 January 2019 - Discussion started: 8 February 2019

Revised: 18 June 2019 - Accepted: 27 June 2019 - Published: 18 July 2019

\begin{abstract}
Dissolved inorganic nitrogen (DIN), including nitrate, nitrite and ammonium, frequently acts as the limitation for primary productivity. Our study focused on the transport and transformation of DIN in a tropical estuary, i.e., the Rajang River estuary, in Borneo, Malaysia. Three cruises were conducted in August 2016 and February-March and September 2017, covering both dry and wet seasons. Before entering the coastal delta, decomposition of the terrestrial organic matter and the subsequent soil leaching was assumed to be the main source of DIN in the river water. In the estuary, decomposition of dissolved organic nitrogen was an additional DIN source, which markedly increased DIN concentrations in August 2016 (dry season). In the wet season (February 2017), ammonium concentrations showed a relatively conservative distribution during the mixing, and the nitrate addition was weak. La Niña events induced high precipitations and discharge rates, decreased reaction intensities of ammonification and nitrification. Hence similar distribution patterns of DIN species in the estuary were found in September 2017 (end of the dry season). The magnitude of riverine DIN flux varied between 77.2 and $101.5 \mathrm{t} \mathrm{N} \mathrm{d}^{-1}$, which might be an important support for the coastal primary productivity.
\end{abstract}

\section{Introduction}

Nitrogen $(\mathrm{N})$ is an essential element for life. The concentration of $\mathrm{N}$ may significantly influence species composition and diversity in terrestrial, freshwater and ocean ecosystems
(Vitousek et al., 1997). Apart from nitrogen gas $\left(\mathrm{N}_{2}\right), \mathrm{N}$ is bioactive with highly variable chemical forms. Dissolved inorganic nitrogen (DIN), including nitrate $\left(\mathrm{NO}_{3}^{-}\right)$, ammonium $\left(\mathrm{NH}_{4}^{+}\right)$and nitrite $\left(\mathrm{NO}_{2}^{-}\right)$, can be easily assimilated by terrestrial plants, algae and bacterial communities (Seitzinger et al., 2002). In addition, due to the high solubility, DIN can be easily transported among ecosystems as a part of the hydrologic cycle (Galloway et al., 2004). Consequently, DIN is assumed to be the most active component in the $\mathrm{N}$ cycle, and the transport of DIN among ecosystems is a hotspot in biogeochemical research on a global scale (Gruber and Galloway, 2008).

Estuaries are the linkage between terrestrial surface water and coastal sea (Seitzinger et al., 2002) and have received much attention from researchers and coastal managers with regard to the quantification of terrestrial DIN transport (e.g., Falco et al., 2010; Holmes et al., 2012; Li et al., 2013; Kuo et al., 2017). The mixing between freshwater and saline water develops physiochemical gradients in various parameters such as dissolved oxygen (DO), salinity and $\mathrm{pH}$ (Spiteri et al., 2008), which influence the growth of distinct bacterial communities (e.g., Goñi-Urriza et al., 2007; Spietz et al., 2015). These bacteria actively participate in DIN transformation processes, such as denitrification, DNRA (dissimilatory nitrate reduction to ammonium) and anammox (anaerobic ammonium oxidation; Burgin and Hamilton, 2007). These processes strongly influence DIN concentrations (Canfield et al., 2010), adding uncertainties to the precise estimation of DIN fluxes. Moreover, environmental parameters related to 
these gradients vary significantly between seasons, leading to a highly dynamic DIN export. Additionally, riparian regions are the focus of anthropogenic processes, including agriculture, manufacturing and wastewater treatment. (Richardson et al., 2007). These activities strongly influence DIN cycling in rivers and estuaries.

Researchers increased the sampling frequency and introduced regional modeling work to improve the understanding of DIN transport and transformation processes. More importantly, stable isotope fractions, e.g., $\delta^{15} \mathrm{~N}-\mathrm{NO}_{3}^{-}, \delta^{18} \mathrm{O}-\mathrm{NO}_{3}^{-}$, and $\delta^{15} \mathrm{~N}-\mathrm{PN}$ (particle nitrogen), have been introduced to trace DIN transport and transformation processes (Middelburg and Nieuwenhuize, 2001). The stable isotope technique has been applied in a number of estuaries located in temperate and sub-tropical zones, such as the Changjiang estuary (China; Yu et al., 2015; Yan et al., 2017), the Seine River estuary (France; Sebilo et al., 2006), the Thames estuary (UK; Middelburg and Nieuwenhuize, 2001) and the Werribee River estuary (Australia; Wong et al., 2014). The delineated reaction pathways and DIN sources/sinks from these research outcomes largely improved our understanding of the DIN cycle, which is crucial for projections as well as the regulation and enactment of laws.

Despite the significant advances made, knowledge gaps in DIN transport via estuaries still exist, with geographic coverage as one of the major shortcomings. As aforementioned, previous research work was intensively conducted in temperate and sub-tropical zones. The tropical zone, characterized by the high annual temperature and intense precipitations, hosts substantial rivers and streams, while studies on DIN transport are scarce, especially in Southeast Asia. The lack of information potentially hampers the holistic understanding of DIN transport from rivers to oceans and increases uncertainties in the global DIN budget estimation (Voss et al., 2013). In addition, since the Second World War, a rapid development in tropical countries has been witnessed. For instance, from 1960 to 2008, the gross national income (GNI) per capita in Malaysia (3.3-5.3) was much higher than the global average level (0.7-1.8; Tran, 2013). Coupled with urbanization, land-use change and population increase, the tropical zone is becoming a hotspot for DIN production, utilization and transport (Seitzinger et al., 2002). The ecological and environmental response in tropical estuaries to the DIN-related anthropogenic pressure is less documented and the magnitudes of river-borne DIN fluxes to coastal lines in the tropical zone are less evaluated. Moreover, the coastal ecosystem in the tropical zone is often complex in structure and harbors substantial seagrass meadow, fishes and coral reefs (Sale et al., 2014). The enhanced intrusion of allochthonous DIN from estuaries to coastal regions might be an ecological risk for local systems (Barbier et al., 2011). Adding these together, it is of urgency and importance to apply robust DIN studies in the tropical zone, and cooperation between researchers from multiple disciplines is highly necessary.
In the present study, three cruises in a typically tropical estuary, i.e., the Rajang River estuary (hereafter Rajang estuary), in Malaysia were conducted, from August 2016 to September 2017, covering both dry and wet seasons. Each cruise started from the upper stream and extended to the coastal ocean. Concentrations of PN, dissolved organic nitrogen (DON) and DIN were determined, and isotope fractions of ${ }^{15} \mathrm{~N}-\mathrm{NO}_{3}^{-}$and $\delta^{18} \mathrm{O}-\mathrm{NO}_{3}^{-}$as well as ${ }^{15} \mathrm{~N}-\mathrm{PN}$ were analyzed accordingly. The research aims for the current research included (1) identification of DIN sources in the river water; (2) exploration of transfers and reactions with regard to DIN at different tributaries in the Rajang estuary and influences on DIN concentrations; and (3) estimation of the magnitude of DIN fluxes injected from the Rajang River to coastal oceans.

\section{Materials and methods}

\subsection{Study site}

The Rajang River (hereafter Rajang) is located in Sarawak state, Borneo (Fig. 1a and b). Sarawak is one of the largest states in Malaysia, with an intensive tropical forest coverage. By 2000, the population in Sarawak was 2.5 million with an urbanization level of $47.9 \%$ (https://www.sarawak. gov.my/web/home/article_view/240/175, last access: October 2018). The climate in Sarawak state is tropical ever-wet (Staub et al., 2000) and is frequently influenced by the El Niño-Southern Oscillation (ENSO) and Madden-Julian Oscillation (Sa'adi et al., 2017). The annual precipitation in the Rajang watershed is approximately $4000 \mathrm{~mm}$, especially in the period from November to the next February due to the Indian Ocean Monsoon (Müller et al., 2015). As a result, this period is usually identified as the wet season and the remaining months are identified as the dry season. The temperature variation was limited between each month and the highest mean daily temperature reached $33^{\circ}$ (Ling et al., 2017).

The Rajang is the largest river in Malaysia, with a length of ca. $530 \mathrm{~km}$. It originates from the Iran Mountains, flows through several cities, such as Kanowit, Song and Sibu, enters the Rajang delta and discharges into the South China Sea (Staub et al., 2000). The watershed coverage is approximately $5.1 \times 10^{4} \mathrm{~km}^{2}$. The river bed in the upper stream was mainly composed of Creaceous-Eocene age sediments. Igneous intrusive and extrusive rocks were observed along the river (Staub et al., 2000). Coupled with precipitation and erosion, suspended particles in the river water were frequently above a level of $200 \mathrm{mg} \mathrm{L}^{-1}$ (Ling et al., 2017; cf. Fig. S1 in the Supplement). After 6000-year accumulation, sediment particles from the upper stream developed a large area of alluvial delta (from Sibu to the estuary mouths). The delta plain is mainly composed of siliciclastic sediments (bottom) and organic-matter-enriched sediments (surface). A substantial fraction of the surface sediments was identified as peat deposits with a maximum depth of $15 \mathrm{~m}$ (Staub et al., 2000). 


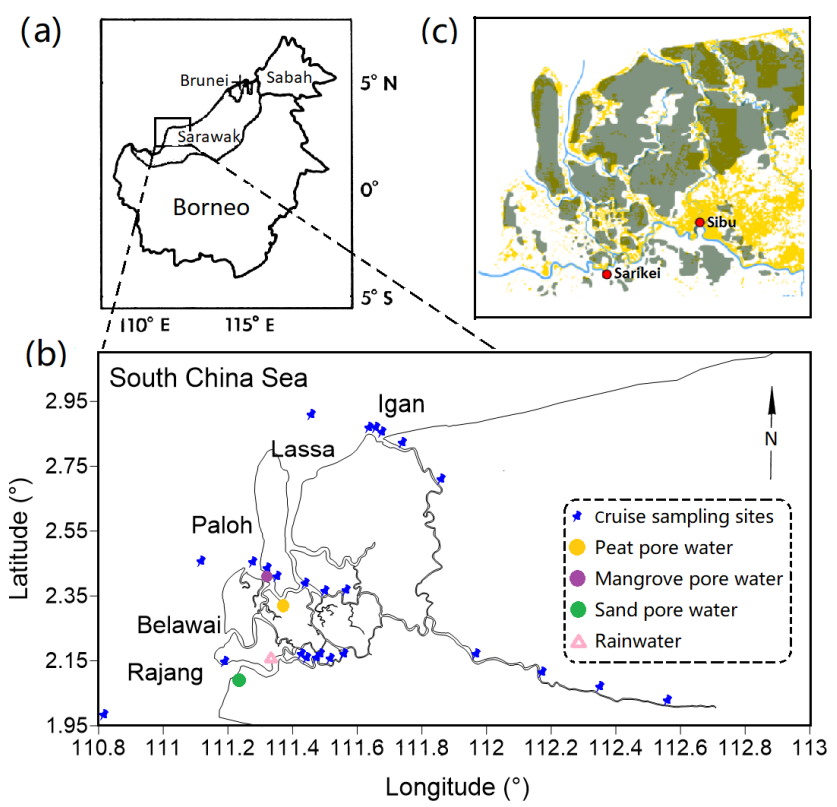

Figure 1. Maps of the sampling area: (a) shows the location of the Rajang lower stream in Borneo, which is invoked from Staub et al. (2000); (b) highlights the sampling sites in the September 2017 cruise; (c) outlines the distribution of peatland in the Rajang lower steam and coastal region (dark green) and deforestation (yellow) in 2010 (Sarawak Geoportal: http://www.bmfmaps.ch, last access: October 2018). The cyan line indicates the Rajang River. The red dots represent Sarikei and Sibu. Both are important cities in the Rajang watershed.

There are four major tributaries in the Rajang delta, namely Rajang, Hulu Seredeng (further separated into two tributaries: Paloh and Lassa), Belawai and Igan (Fig. 1b). Apart from the Rajang tributary, the peat deposits were frequently observed in the remaining three tributaries (Fig. 1c). The tidal range in the Rajang estuary is from 2.8 to $5.6 \mathrm{~m}$ and decreases from the Rajang tributary (macro tidal range) to the Igan tributary (meso tidal range). The saltwater intrusion could reach the downstream of Sibu with a few kilometers to the city (Müller-Dum et al., 2019). The total discharge rate of the Rajang was estimated to be 3000 to $6000 \mathrm{~m}^{3} \mathrm{~s}^{-1}$, depending on seasons. The river water mainly injects through the Igan branch to the South China Sea (Jakhrani et al., 2013). The Rajang and its delta play an important role in the national economy. Fishery, logging and timber processing are traditional supports for local citizens (Salam and Gopinath, 2006; Miettinen et al., 2016). In addition, industry plantations for oil palm and acacia have boomed recently (Lam et al., 2009), occupying more than $50 \%$ peatland $(11 \%$ of the catchment size) in the Rajang watershed (Miettinen et al., 2016). These activities have led to patchy deforestation, from the upper steam to the coastal delta (Fig. 1c).

\subsection{Cruises and sample collection}

Three cruises were conducted during 2016-2017, covering two dry seasons (August 2016, September 2017) and a wet season (February to March 2017). The sampling in each cruise included the river water sites and brackish water sites in the Igan, Lassa-Paloh and Rajang tributaries. High-salinity water samples $(>30 \%$ o ) from the adjacent coastal ocean were also collected. The total sampling sites in each cruise ranged between 16 and 32 stations. In September 2017, porewater samples from the edge of a mangrove forest, peatland and coastal sandy beach were collected. Rainwater was gathered once during the September cruise.

The river water and coastal seawater were collected into $1 \mathrm{~L}$ acid-prewashed high-density polyethylene (HDPE) sampling bottles via a pole sampler that decreases the contamination from boat surface and engine cooling water (Zhang et al., 2015). Apart from four stations in September 2017, salinity, temperature, $\mathrm{DO}$ and $\mathrm{pH}$ were measured in situ by an Aquaread $^{\circledR}$ multiple-parameter probe (AP-2000). For porewater samples, a sampling hole with a depth of approximately $20 \mathrm{~cm}$ was dug at low tide. The seeped pore water that accumulated in the bottom of the sampling hole was discarded three times before collection. Subsequently, pore water was sucked into a $50 \mathrm{~mL}$ syringe and then transferred to $250 \mathrm{~mL}$ acid-prewashed sampling bottles. The rainwater was collected under the roof at a local primary school in a strong precipitation event. The rainwater from the first 10 min was discarded. Salinity of the pore water and rainwater was determined by a refractometer.

The filtration was conducted immediately after sampling. The harvest water samples were shaken and then divided into two portions (excluding pore water and rainwater). The first portion was filtered via polycarbonate membrane filters $\left(0.4 \mu \mathrm{m}\right.$ pore size, Whatman $\left.{ }^{\circledR}\right)$ into $60 \mathrm{~mL}$ sampling bottles for the determination of dissolved nitrogen species in three cruises and $\mathrm{NO}_{3}^{-}$isotope fractions $\left({ }^{15} \mathrm{~N}-\mathrm{NO}_{3}^{-}\right.$and ${ }^{18} \mathrm{O}-$ $\mathrm{NO}_{3}^{-}$) in the last two cruises. The other portion was filtered via pre-combusted $\left(450^{\circ}, 4 \mathrm{~h}\right)$ glass fiber filters (average pore size $0.7 \mu \mathrm{m}$, Whatman ${ }^{\circledR}$ ) for the analyses of suspended particle matter (SPM) and PN concentrations, as well as $\delta^{15} \mathrm{~N}-$ PN. Both liquid and membrane samples were kept at a $-20^{\circ}$ environment until laboratory analyses.

\subsection{Mixing experiments}

In September 2017, a mixing experiment was conducted to explore the influence of river-borne suspended particles on DIN transformation along the salinity gradient. In particular, river water samples (salinity: 0) from Sibu (10 km downstream from the city dock) and the coastal ocean (salinity: $32 \%$ ) were collected. All the seawater and half of the river water were filtered through polycarbonate membrane filters to remove particle matters. The first treatment group was assigned to be the mixture between the filtered seawater and 
the particle-free river water. In practice, they were mixed and placed in $1 \mathrm{~L}$ acid prewashed HDPE bottles with a volume of $500 \mathrm{~mL}$. The percentage of river water in the system was $0 \%$ (purely filtered seawater), $25 \%, 50 \%, 75 \%$ and $100 \%$ (pure river water). The second treatment group contained filtered seawater and unfiltered river water, while the total volume and percentage of river water were identical to the first treatment. The HDPE bottles were placed in the dark at 25$26^{\circ}$ for $24 \mathrm{~h}$. During the incubation, all the bottles were rotated to sustain the suspension of particles. Afterwards, the whole mixture was filtered again and the liquid was stored in $60 \mathrm{~mL}$ bottles in a freezer for the determination of DIN, $\mathrm{DON}, \delta^{15} \mathrm{~N}-\mathrm{NO}_{3}^{-}$and $\delta^{18} \mathrm{O}-\mathrm{NO}_{3}^{-}$.

\subsection{Laboratory analyses}

After thawing and thorough remixing, concentrations of $\mathrm{NH}_{4}^{+}, \mathrm{NO}_{2}^{-}$and $\mathrm{NO}_{3}^{-}$were determined on a flow-through injection system (SKALAR Analytical B.V., the Netherlands) using standard colorimetric methods (Grasshoff et al., 2007) after modification by the manufacturers. The determination limit for these species was below $0.1 \mu \mathrm{M}$ and the analysis precision was $3.5 \%$. The content of total dissolved nitrogen (TDN) was measured by the potassium persulfate digestion method $\left(121^{\circ}, 30\right.$ min digestion) according to Ebina et al. (1983). The difference in the concentration between TDN and DIN was assumed to be the level of DON. Both $\delta^{15} \mathrm{~N}-$ $\mathrm{NO}_{3}^{-}$and $\delta^{18} \mathrm{O}-\mathrm{NO}_{3}^{-}$were determined using the bacterial reduction method on the basis of Weigand et al. (2016). In practice, $\mathrm{NO}_{3}^{-}$in the water samples was transformed into $\mathrm{N}_{2} \mathrm{O}$ via the denitrifier (P. aureofaciens; Sigman et al., 2001) after removal of $\mathrm{NO}_{2}^{-}$by sulfanilamide acid solution (Weigand et al., 2016). The produced $\mathrm{N}_{2} \mathrm{O}$ was injected into a ThermoFisher Precon system (Thermo Fisher, USA) and then flowed through Finngan chromatographical loops and finally into a Thermo-Fisher Delta V isotope system. The calculation from the $\mathrm{N}_{2} \mathrm{O}$ isotope fraction to $\delta^{15} \mathrm{~N}-\mathrm{NO}_{3}^{-}$and $\delta^{18} \mathrm{O}-\mathrm{NO}_{3}^{-}$ followed Casciotti and Mcilvin (2007). The determination limit for the original $\mathrm{NO}_{3}^{-}$concentration was approximately $0.9 \mu \mathrm{M}$. The method precision was $0.2 \% \circ\left(\delta^{15} \mathrm{~N}-\mathrm{NO}_{3}^{-}\right)$and $0.5 \%$ o $\left(\delta^{18} \mathrm{O}-\mathrm{NO}_{3}^{-}\right)$, respectively.

\subsection{Mathematical analyses}

To understand the addition or removal of solutes during the mixing, a two-endmember mixing model (Liss, 1976) used for the conservative distribution of solute concentration and related isotope fractionations was invoked:

$N_{\text {mix }}=f_{\mathrm{r}} \times N_{\mathrm{r}}+\left(1-f_{\mathrm{r}}\right) \times N_{\mathrm{o}}$,

where $N_{\text {mix }}$ is the conservative concentration of a specific $\mathrm{N}$ solute at a particular salinity; $N_{\mathrm{r}}$ is the solute concentration at the freshwater endmember (obtained from the starting site in each tributary); $N_{\mathrm{o}}$ is the concentration at the ocean endmember (the high-salinity site near each tributary outlet); $f_{\mathrm{r}}$ is the fraction of fresh river water, which is calculated as

$f_{\mathrm{r}}=\left(S_{\mathrm{o}}-S_{\mathrm{mix}}\right) /\left(S_{\mathrm{o}}-S_{\mathrm{r}}\right)$,

where $S_{\mathrm{mix}}$ is the sample salinity; $S_{\mathrm{r}}$ and $S_{\mathrm{o}}$ are salinity at the river and saline water, respectively. For the conservative isotope fraction in each sample, it can be calculated as

$\delta_{\text {mix }}=\left[f_{\mathrm{r}} \times N_{\mathrm{r}} \times \delta_{\mathrm{r}}+\left(1-f_{\mathrm{r}}\right) \times N_{\mathrm{o}} \times \delta_{\mathrm{o}}\right] / N_{\text {mix }}$,

where $\delta_{\text {mix }}$ is the conservative isotope fraction, such as $\delta^{15} \mathrm{~N}-$ $\mathrm{NO}_{3}^{-}$or $\delta^{18} \mathrm{O}-\mathrm{NO}_{3}^{-} ; \delta_{\mathrm{r}}$ and $\delta_{\mathrm{o}}$ are isotope values in the river and seawater, respectively. The difference in concentration between the conservative and observed levels was defined as the offset concentration, i.e., an indicator for benthic $\mathrm{N}$ reactions. Considering the limited distance and similar environmental settings between the Polah and Lassa tributaries, the measurement data from these two tributaries were merged together in the calculation and related plots.

Total DIN fluxes $(Q)$ transported to the coastal ocean were estimated according to the following equation:

$Q=C \times V \times\left(\left(f_{\text {Rajang }}+f_{\text {Lassa }}+f_{\text {Igan }}\right) / 3\right)$,

where $C$ is the mean concentration of DIN species at the fresh river water (salinity: 0 ), $V$ is the river water discharge $\left(3000 \mathrm{~m}^{3} \mathrm{~s}^{-1}\right.$ in the dry season, $6000 \mathrm{~m}^{3} \mathrm{~s}^{-1}$ in the wet season), and $f$ is the reaction factor for each DIN species. It was estimated on the basis of concentration differences between the observed pattern and the conservative distribution for each solute (calculation process described in the legend of Fig. S2) in each tributary (i.e., $f_{\text {Rajang }}, f_{\text {Lassa }}$ and $f_{\text {Igan }}$ ). The value $>1$ indicates the solute addition during the mixing and vice versa. The magnitude of $f$ is closely linked to the magnitude of reaction intensity in addition/removal at the estuary. In the flux calculation, the average $\left(\left(f_{\text {Rajang }}+f_{\text {Lassa }}+\right.\right.$ $\left.f_{\text {Igan }}\right) / 3$ ) from three tributaries was used.

All the statistical analyses, such as a Student's $t$ test and linear regression, were conducted in Minitab 17.0 (Minitab Inc., Pennsylvania State University, USA). The significant threshold for all the analyses was $\alpha=0.05$.

\subsection{Data plot}

The spatial distribution of each parameter, e.g., salinity, temperature and solute concentration, was plotted in Surfer 14.0 (Golden Software Inc., USA), and the dot plots were done in Sigmaplot 12.5 (Systat Software Inc., USA). Given the limited space, a portion of the plots were displayed in the Supplement (Figs. S3 to S11).

\section{Results}

\subsection{Water chemistry}

In August 2016, the salinity in the sampled water ranged from $0.02 \%$ to $31.2 \%$ (Fig. 2). A similar salinity range 

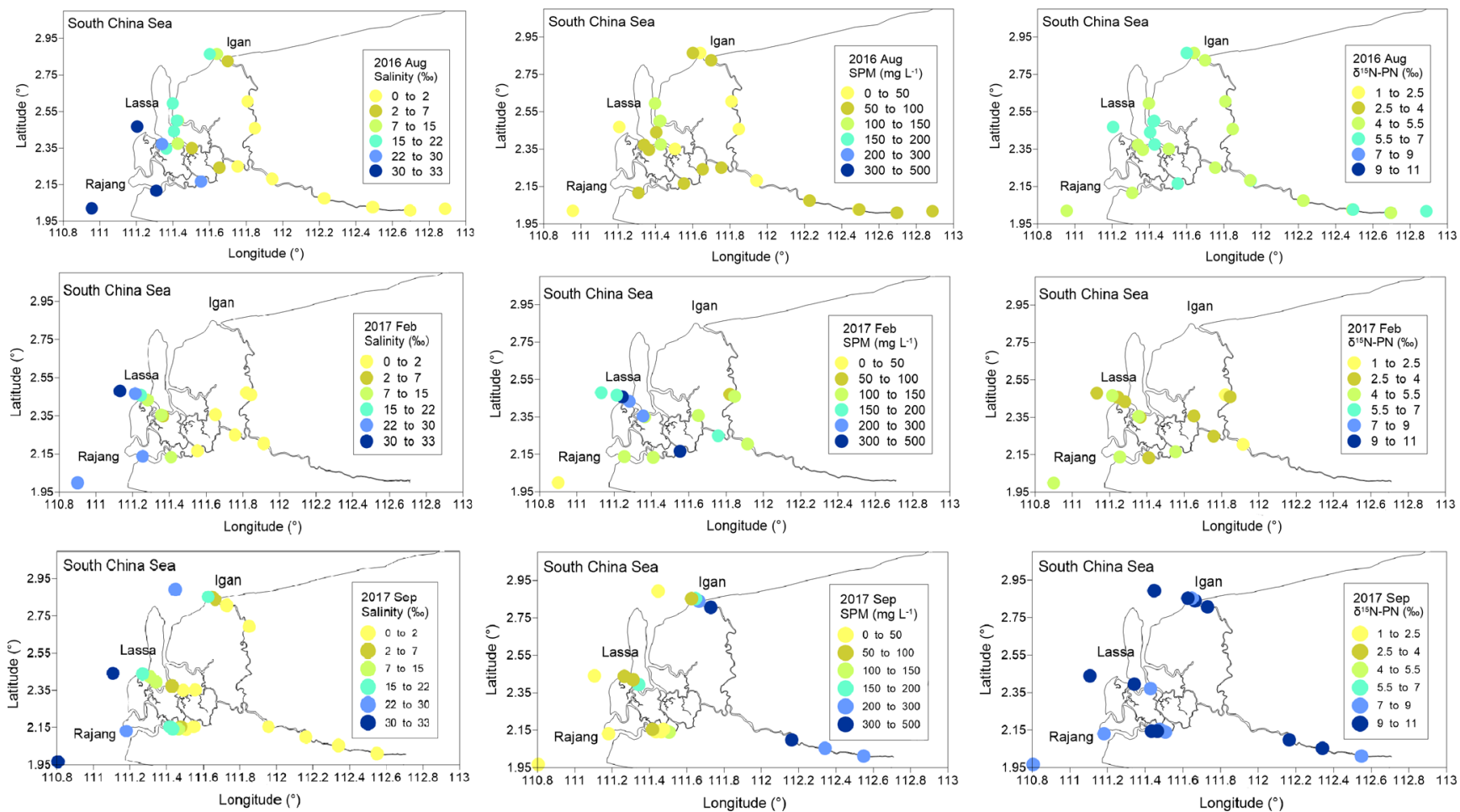

Figure 2. Distribution of salinity, suspended particle matter (SPM) and $\delta^{15} \mathrm{~N}-\mathrm{PN}$ in the Rajang estuary and the adjacent coastal ocean.

was observed in the remaining cruises. The water temperature ranged from 27.7 to $31.8^{\circ}$ in August 2016 and the variation among cruises was also limited. The $\mathrm{pH}$ varied from 6.03 to 8.12 and displayed a steady increase from the river water to coastal oceans (Figs. S3 and S4). DO fell in the range between 8.2 and $2.7 \mathrm{mg} \mathrm{L}^{-1}$. The $\mathrm{DO}$ content in the majority of sites was undersaturated, especially in the August cruise. Accordingly, the oxygen undersaturation degree (OUD), i.e., the difference between DO saturation level and observed DO concentration, was calculated. It varied from 0.6 to $132 \mu \mathrm{mol} \mathrm{L}^{-1}$ and decreased from fresh river water to coastal saline water (Fig. S5). In the light of the seasonality, the mean OUD at the fresh river water and the estuary in three tributaries in August 2016 was significantly higher than the values from the remaining two cruises.

\subsection{Particle nitrogen and its isotope fraction}

In August 2016, SPM concentrations ranged from 24 to $120 \mathrm{mg} \mathrm{L}^{-1}$ (Fig. 2). Compared with the coastal ocean (24 $\left.\mathrm{m} \mathrm{L}^{-1}\right)$, the SPM content in the river water was markedly higher, and the presence of an estuarine turbidity maximum was obtained in the river branches. In the cruises in 2017, the SPM concentration in the river water markedly increased (exceeding $500 \mathrm{mg} \mathrm{L}^{-1}$ ). By contrast, the SPM content in the ocean endmember was similar among cruises. Percentages of PN in SPM varied between $0.1 \%$ and $0.6 \%$ (Fig. S6). The PN concentration, i.e., the multiplication prod- uct of SPM concentration and PN percentage, varied from 5.0 to $40.7 \mu \mathrm{M}$ (Fig. S6). Due to the low concentration of SPM, the range of PN concentration in August 2016 was lower than that obtained from February and September 2017. The $\delta^{15} \mathrm{~N}-$ PN from three cruises was from $1.9 \%$ to $11.8 \%$ (Fig. 2). Apart from several sites in the mixing zone, $\delta^{15} \mathrm{~N}-\mathrm{PN}$ in the fresh river water and seawater was similar. A seasonal variation in $\delta^{15} \mathrm{~N}-\mathrm{PN}$ was found. The highest value was observed in September 2017, while the lowest fraction was obtained in February 2017 (Fig. 2).

\subsection{Dissolved nitrogen and related isotope fractions}

Compared with the PN concentration, the content of dissolved fractions was relatively minor. In August 2016, DON concentrations varied from 2.6 to $14.8 \mu \mathrm{M}$, and high levels were found in estuary channels (Fig. S8). In the remaining two cruises, DON concentrations in many sites were comparable to the range obtained from the first cruise. $\mathrm{NH}_{4}^{+}$concentrations were 0.39 to $17.3 \mu \mathrm{M}$ (Fig. 3). Similarly to DON, the seasonal variation in $\mathrm{NH}_{4}^{+}$concentrations was minor. In the estuary, a slight increase in the $\mathrm{NH}_{4}^{+}$concentration during the August cruise was found (Fig. 4), especially in the Lassa tributary, while the remaining two cruises showed a limited variation. For $\mathrm{NO}_{3}^{-}$concentrations, a range from 1.6 to $14.8 \mu \mathrm{M}$ was found in August 2016 (Fig. 3). Concentrations in the remaining two cruises slightly decreased. The highest concentration was below $10 \mu \mathrm{M}$. The similar $\mathrm{NO}_{3}^{-}$ 

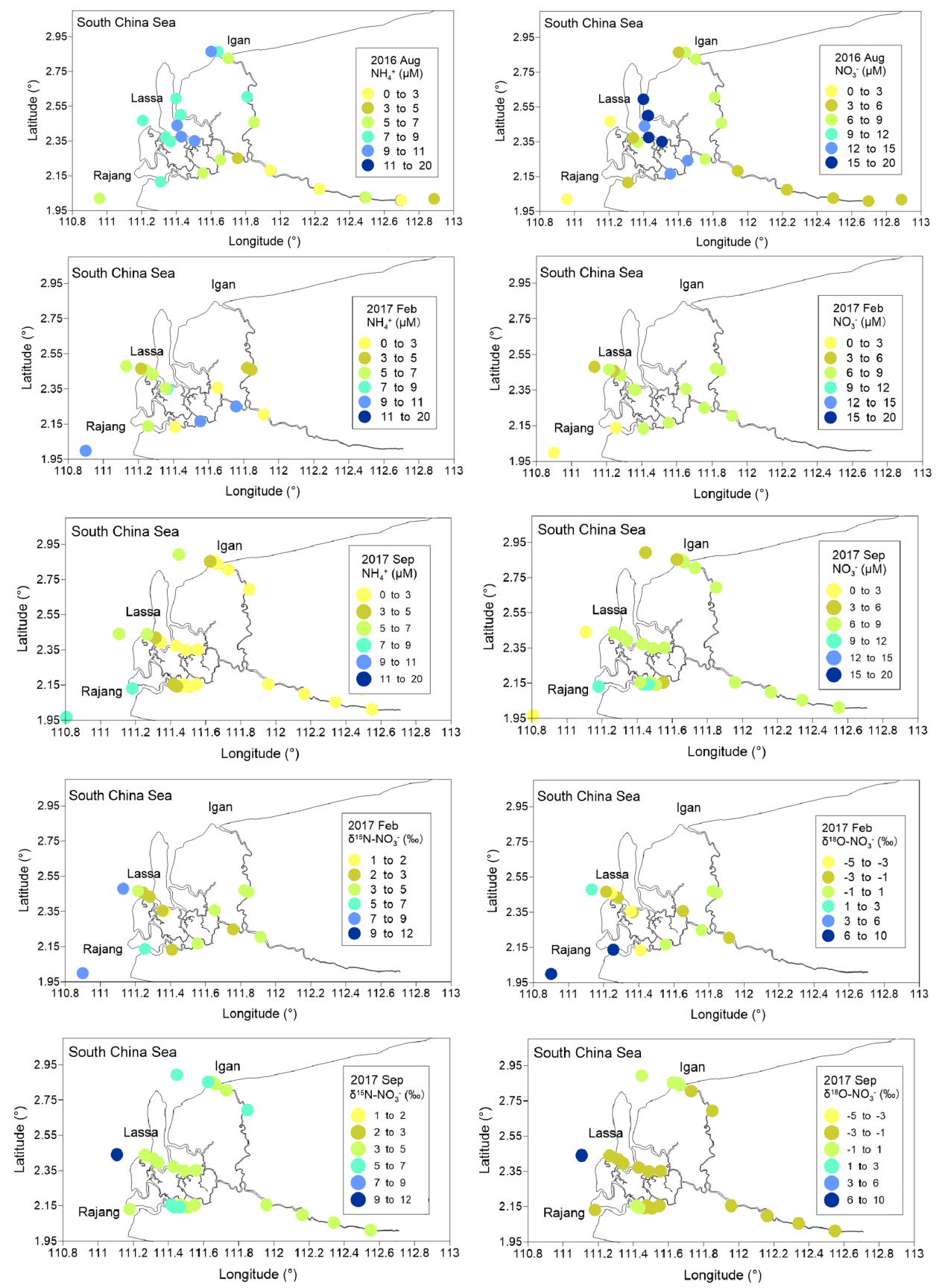

Figure 3. Concentrations of $\mathrm{NH}_{4}^{+}$and $\mathrm{NO}_{3}^{-}$, as well as its stable isotope fractions $\left(\delta^{15} \mathrm{~N}-\mathrm{NO}_{3}^{-}\right.$and $\left.\delta^{18} \mathrm{O}-\mathrm{NO}_{3}^{-}\right)$, in the Rajang estuary and adjacent coastal ocean.

concentration distribution in 2017 cruises led to an insignificant variation in the range for $\delta^{15} \mathrm{~N}-\mathrm{NO}_{3}^{-}$and $\delta^{18} \mathrm{O}-\mathrm{NO}_{3}^{-}$ between seasons (Fig. 3). In terms of $\mathrm{NO}_{2}^{-}$, i.e., the minimum component in the DIN inventory, the concentration varied between 0.09 and $3.3 \mu \mathrm{M}$ in August 2016. Similar levels were found in the remaining samples.

Along the salinity gradient, positive offsets (a positive deviation from conservative mixing) for $\mathrm{NO}_{3}^{-}$concentration were frequently observed, especially in the Lassa and Igan, which suggests net generations $\left(\mathrm{NO}_{3}^{-}\right.$release) during the mixing (Fig. 5). Coupled with the $\mathrm{NO}_{3}^{-}$generation, negative offsets in $\delta^{15} \mathrm{~N}-\mathrm{NO}_{3}^{-}$and $\delta^{18} \mathrm{O}-\mathrm{NO}_{3}^{-}$at most sites were observed (Fig. 5). The offsets of $\delta^{15} \mathrm{~N}-\mathrm{NO}_{3}^{-}$and $\delta^{18} \mathrm{O}-\mathrm{NO}_{3}^{-}$ were linearly correlated (Fig. 5). The slope was 0.99 and $R^{2}$ was $0.63(p<0.05)$. 

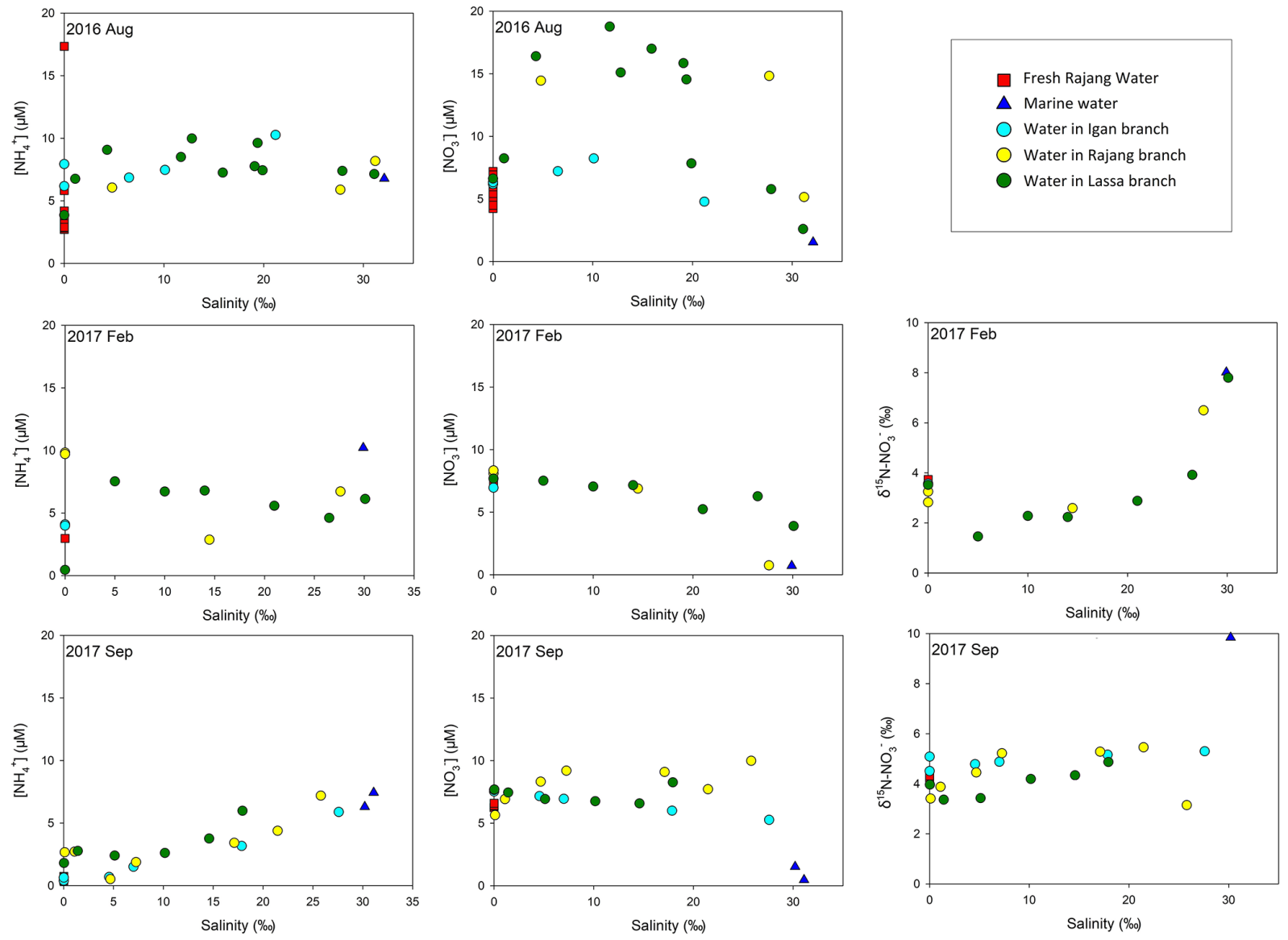

Figure 4. Distribution of $\mathrm{NH}_{4}^{+}$and $\mathrm{NO}_{3}^{-}$concentrations, as well as $\delta^{15} \mathrm{~N}_{-} \mathrm{NO}_{3}^{-}$, along the salinity gradient in the Rajang estuary.

\subsection{Mixing experiments}

In the particle-free (filtered) group, the mean DON concentration was $7.1 \mu \mathrm{M}$ in the river water and $4.7 \mu \mathrm{M}$ in the seawater (Fig. 6). In the experiment, DON concentrations slightly departed from the conservative mixing. A similar pattern was found in the unfiltered (particle-contained) group. Different from $\mathrm{DON}, \mathrm{NH}_{4}^{+}$concentrations in both groups were nearly conservative and the concentration difference between groups was minor. For $\mathrm{NO}_{3}^{-}$, apart from the seawater (identical between groups), the concentration in the particlecontained group was markedly lower than that in the filtered group. As a mirror of concentration variation, $\delta^{15} \mathrm{~N}-\mathrm{NO}_{3}^{-}$ and $\delta^{18} \mathrm{O}-\mathrm{NO}_{3}^{-}$elevated in the particle-contained group. Furthermore, compared to the conservative distribution, a deficit in $\mathrm{NO}_{3}^{-}$content in the brackish water (salinity: $24 \%$ ) in the unfiltered group was obtained. Concurrently, increases in both $\delta^{15} \mathrm{~N}-\mathrm{NO}_{3}^{-}$and $\delta^{18} \mathrm{O}-\mathrm{NO}_{3}^{-}$at the identical salinity were observed. For $\mathrm{NO}_{2}^{-}$, the unfiltered group showed a strong removal, while the filtered group maintained a conservative distribution (Fig. 6).

\subsection{Pore water and rainwater}

The salinity of the rainwater was 0 (Table 1). The concentration of $\mathrm{NH}_{4}^{+}$was $18.9 \mu \mathrm{M}$. The $\mathrm{NO}_{3}^{-}$level was $16.4 \mu \mathrm{M}$ with a markedly high value of $\delta^{18} \mathrm{O}-\mathrm{NO}_{3}^{-}(55.3 \%$ o $)$ compared to the river water. Salinities of porewater samples varied from $1.0 \%$ to $21.5 \%$. These samples were enriched with $\mathrm{NH}_{4}^{+}$ $(22.8$ to $121 \mu \mathrm{M})$ and DON (34.5 to $89.2 \mu \mathrm{M})$. In comparison, levels of $\mathrm{NO}_{3}^{-}$and $\mathrm{NO}_{2}^{-}$in porewater samples were low $(<1.2 \mu \mathrm{M})$. Isotope fractions were similar to the river water.

\section{Discussion}

\subsection{DIN sources in the Rajang River water}

The Rajang is the largest river in Sarawak and receives substantial materials from its watershed. In the present study, we collected samples in the drainage basin (river water, salinity 0 ) and the estuarine. In the river water, the proportion of DIN in the $\mathrm{N}$ inventory was minor, accounting for $20 \%$ to $30 \%$ (Fig. 7a). In comparison to rivers located in dense population areas, such as the Pearl River in China, the Mississippi River in the USA, the Danshui River in Taiwan, China, and 

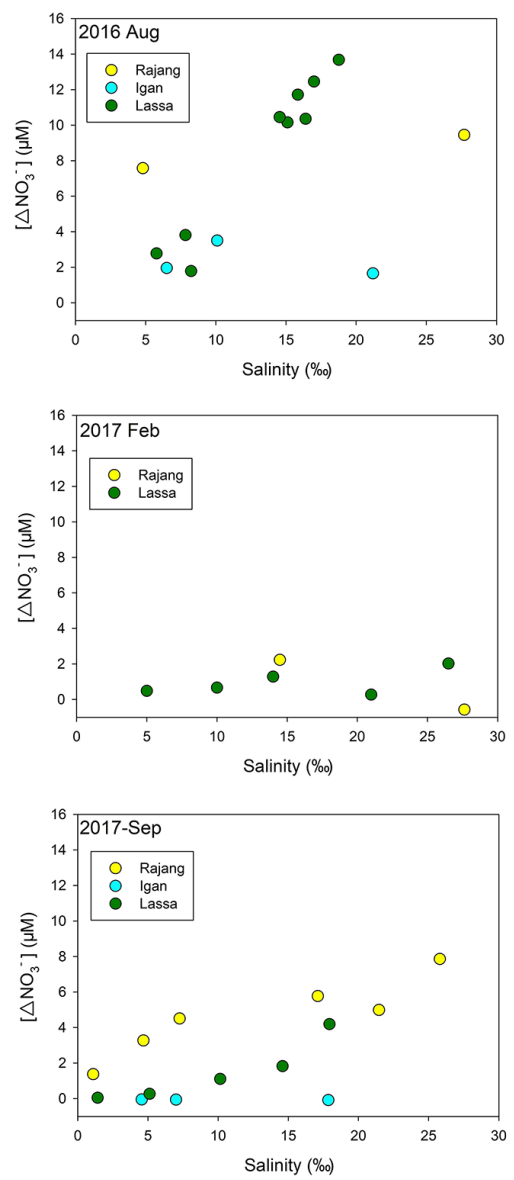
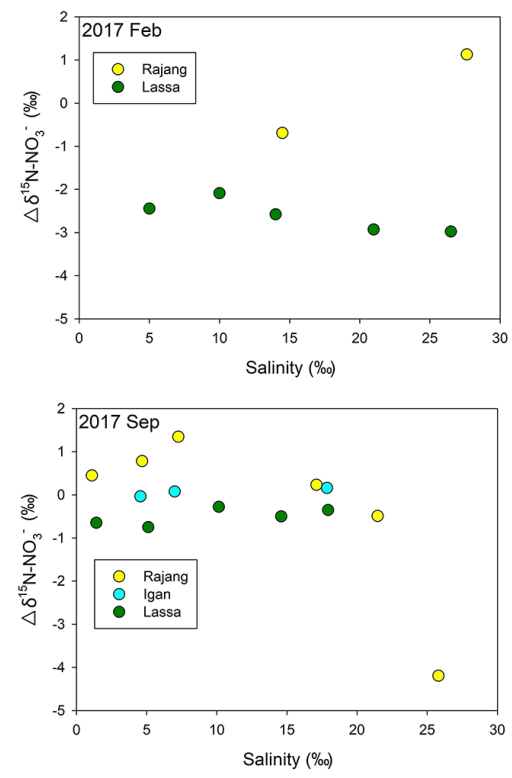
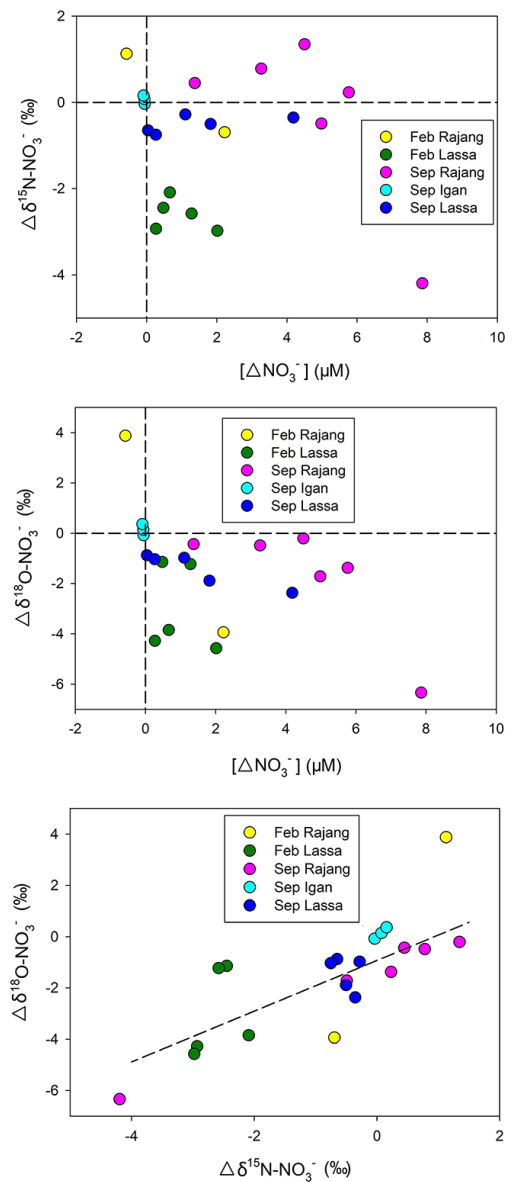

Figure 5. Distribution of the $\mathrm{NO}_{3}^{-}$concentration offset ([ $\left.\Delta \mathrm{NO}_{3}^{-}\right]$in the figure) in three Rajang tributaries (Igan, Lassa and Rajang) along the salinity gradient from three cruises; distribution of the $\delta^{15} \mathrm{~N}-\mathrm{NO}_{3}^{-}$offset $\left(\Delta \delta^{15} \mathrm{~N}-\mathrm{NO}_{3}^{-}\right.$in the figure) in three Rajang tributaries along the salinity gradient in 2017; comparison between the $\delta^{15} \mathrm{~N} /{ }^{18} \mathrm{O}-\mathrm{NO}_{3}^{-}$offset and the $\mathrm{NO}_{3}^{-}$concentration offset for the cruises in 2017; correlation between $\delta^{15} \mathrm{~N}-\mathrm{NO}_{3}^{-}$and the ${ }^{18} \mathrm{O}-\mathrm{NO}_{3}^{-}$offset, the slope of the correlation curve between $\delta^{15} \mathrm{~N}-\mathrm{NO}_{3}^{-}$and $\delta^{18} \mathrm{O}-\mathrm{NO}-{ }_{3}^{-}$being $0.99\left(R^{2}: 0.64\right)$.

Table 1. Chemical properties in the rainwater and pore water from mangrove swamp, sandy beach and peatland.

\begin{tabular}{lrrrrrrr}
\hline Sample & Salinity $(\% o)$ & $\mathrm{NH}_{4}^{+}(\mu \mathrm{M})$ & $\mathrm{NO}_{2}^{-}(\mu \mathrm{M})$ & $\mathrm{NO}_{3}^{-}(\mu \mathrm{M})$ & $\delta^{15} \mathrm{~N}-\mathrm{NO}_{3}^{-}(\% o)$ & $\delta^{18} \mathrm{O}-\mathrm{NO}_{3}^{-}(\% o)$ & $\mathrm{DON}(\mu \mathrm{M})$ \\
\hline Rainwater & 0 & 18.9 & 0.05 & 16.4 & 5.2 & 55.3 & 22.3 \\
Mangrove & 21.5 & 33.4 & 0.36 & 1.0 & 3.7 & 2.6 & 46.2 \\
Sandy beach & 17.5 & 22.8 & 0.05 & 0.3 & - & - & 34.5 \\
Peatland & 1.0 & 121 & 0.63 & 1.2 & 3.8 & 2.1 & 89.2 \\
\hline
\end{tabular}

the Mekong River in Vietnam, concentrations of $\mathrm{NO}_{3}^{-}$and $\mathrm{NH}_{4}^{+}$in the Rajang water were low (Table 2).

In Fig. $7 \mathrm{~b}, \delta^{18} \mathrm{O}-\mathrm{NO}_{3}^{-}$and $\delta^{15} \mathrm{~N}-\mathrm{NO}_{3}^{-}$were plotted together to identify the potential sources of $\mathrm{NO}_{3}^{-}$. Apart from errors introduced from biogeochemical reactions on the signal, according to the isotope composition in different sources, the decomposition of the terrestrial organic matter and its subsequent leaching from soils were an important source of $\mathrm{NO}_{3}^{-}$in the river water. Despite the relatively low DIN concentration, the DIN yield of the Rajang was higher than values from other tropical rivers due to higher ENSO-induced rainfall and the resulting high surface water discharges (Fig. 7c and d). Among the tropical rivers around the South China Sea, e.g., the Mae Klong River in Thailand and the Langat River in Malaysia (Malaysian Peninsula), the yield in $\mathrm{NH}_{4}^{+}$and $\mathrm{NO}_{3}^{-}$in the Rajang in August 2016 was higher (Fig. 7c). The $\mathrm{NH}_{4}^{+}$production is even higher than that of the Wanquan River (China), which features inten- 

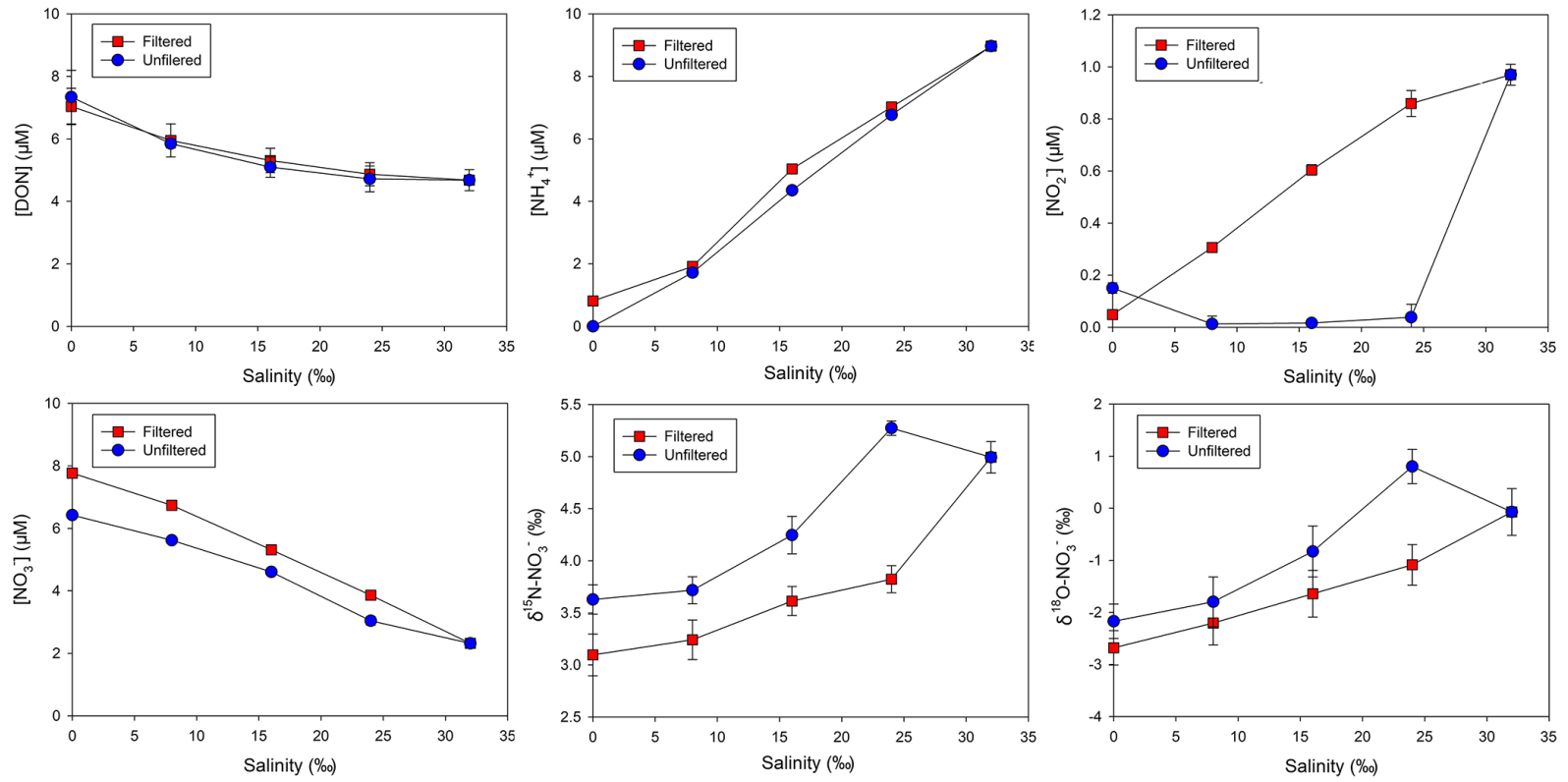

Figure 6. Concentrations of $\mathrm{DON}, \mathrm{NO}_{3}^{-}, \mathrm{NH}_{4}^{+}$and $\mathrm{NO}_{2}^{-}$, as well as $\delta^{15} \mathrm{~N}-\mathrm{NO}_{3}^{-}$and $\delta^{18} \mathrm{O}-\mathrm{NO}_{3}^{-}$, in the mixing experiment (mean \pm standard deviation).

Table 2. A global view of the $\mathrm{NH}_{4}^{+}$and $\mathrm{NO}_{3}^{-}$concentration in the fresh river water and the magnitude of riverine DIN flux.

\begin{tabular}{lrrrl}
\hline Site & $\mathrm{NH}_{4}^{+}(\mu \mathrm{M})$ & $\mathrm{NO}_{2+3}^{-}(\mu \mathrm{M})$ & DIN flux (t N d $\left.{ }^{-1}\right)$ & Reference \\
\hline Rajang River (Malaysia) $^{\mathrm{a}}$ & 5.5 & 5.4 & 77.2 & This study \\
Mekong River (Vietnam) $^{-11}$ & 15 & 789 & Iida et al. (2007), Liljeström et al. (2012) \\
Danshui River (Taiwan, China) & 137 & 57.1 & 49.1 & Kuo et al. (2017) \\
Pearl River (China) & 207 & 211 & 468 & Cai et al. (2015) \\
Amazon River (Brazil) & 0.2 & 11.8 & 2322 & Santos et al. (2008) \\
Mississippi River (USA) & 0.9 & 113 & 3720 & Battaglin et al. (2010) \\
Meghna River (Bangladesh) & 0.1 & 15.8 & 85.0 & Uddin et al. (2014) \\
Pangani River (Tanzania) & 4.5 & 42.8 & 0.87 & Selemani et al. (2017) \\
Tana River (Kenya) & 0.62 & 9.6 & 1.57 & Bouillon et al. (2009) \\
Wanquan River (China) & 21 & 157 & 10.2 & Li et al. (2013) \\
\hline
\end{tabular}

${ }^{\mathrm{a}}$ Dry season record. ${ }^{\mathrm{b}}$ Monsoon Season record.

sive human activities and a large number of tourists. Such a high yield may result from the abundant storage of organic matter and ammonification-induced $\mathrm{NH}_{4}^{+}$accumulation in Sarawak peatland (Melling et al., 2007). Moreover, because of the overlap in isotope signals (Fig. 7b), fertilizers may also be deemed to be responsible for the DIN yield. In particular, DIN concentrations in the river water exceeded those detected in pristine tropical black water rivers (Baum and Rixen, 2014), suggesting a potential influence from anthropogenic activities. In Sarawak, the chemical fertilizer requirement in oil palm plantation (Tarmizi and Mohd Tayeb, 2006) may be the most likely DIN source since the unconsumed fertilizer likely drained into the Rajang water coupled with precipitations.
Notably, levels of $\mathrm{NO}_{2}^{-}$and $\mathrm{NO}_{3}^{-}$in the river water were stable among cruises, while the $\mathrm{NH}_{4}^{+}$concentration significantly varied in two dry seasons. Apart from dilution, biogeochemical production for $\mathrm{NH}_{4}^{+}$also influences its concentration. Specifically, $\mathrm{NH}_{4}^{+}$can be the reaction output of DON and PN mineralization and subsequent ammonification in the upper stream water. The transformation can occur in terrestrial aquifers and/or the Rajang. Among cruises, the concentration of DON was stable. The level of PN increased in September 2017 (Fig. 7a). Consequently, the production of $\mathrm{NH}_{4}^{+}$may not be constrained in the water and the drop in $\mathrm{NH}_{4}^{+}$concentration resulted from the declined $\mathrm{NH}_{4}^{+}$production in terrestrial soils. Generally, ammonification in soils is strongly dependent on the moisture content (Hopmans et al., 1980). A strong El Niño event was ob- 

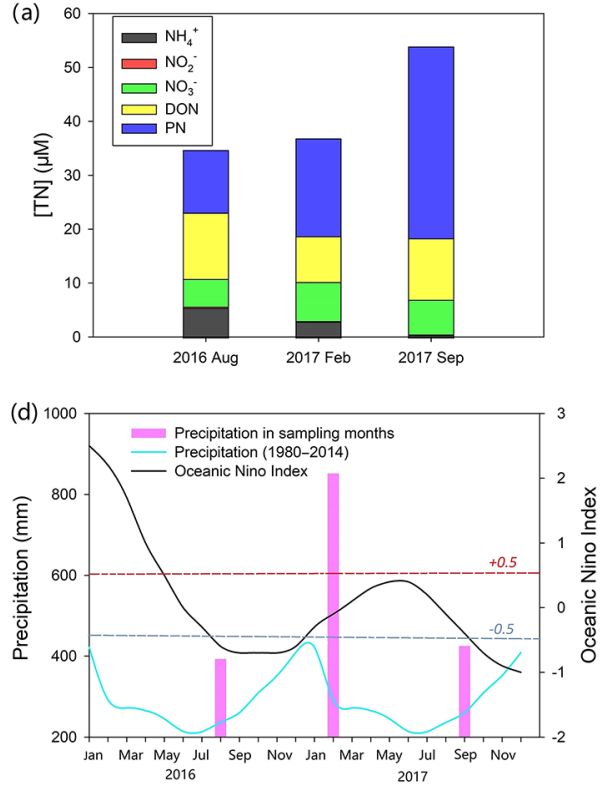
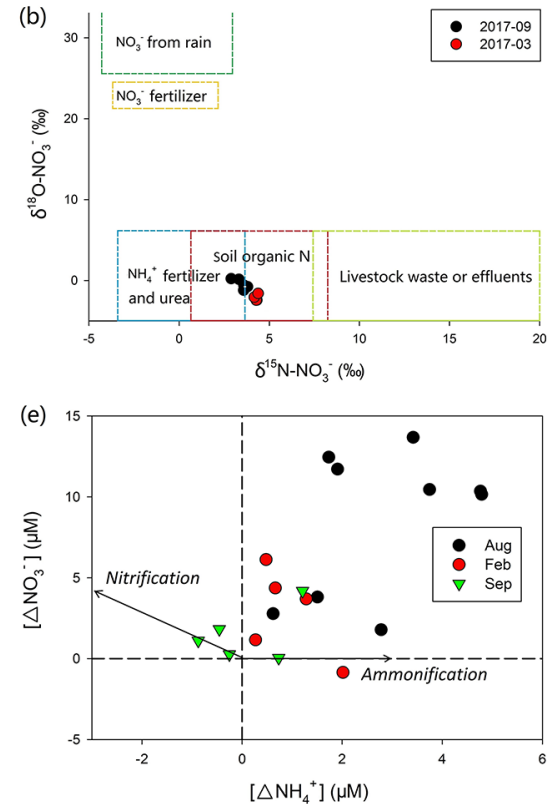
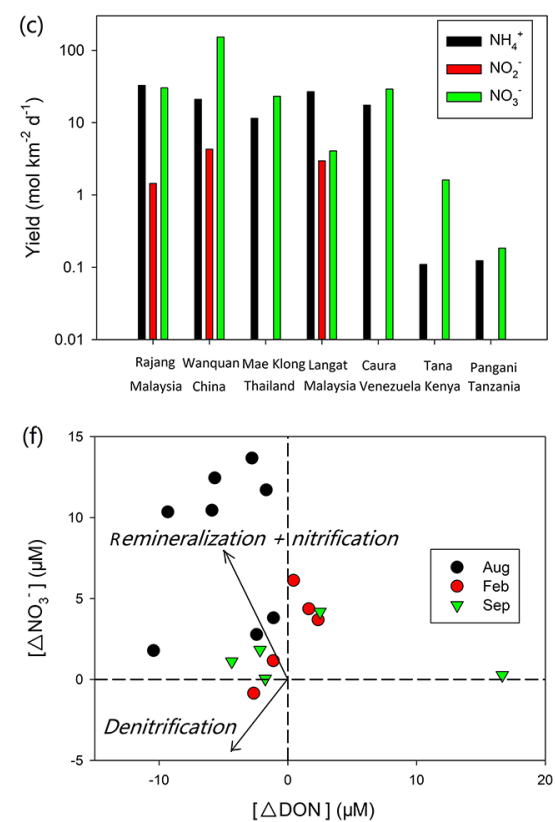

Figure 7. (a) Mean concentration of different $\mathrm{N}$ species in the fresh Rajang water (salinity: 0, sampling sites ranged from the upper stream to Sibu); (b) $\delta^{15} \mathrm{~N}-\mathrm{NO}_{3}^{-}$to $\delta^{18} \mathrm{O}-\mathrm{NO}_{3}^{-}$in the fresh Rajang water. The figure also highlights the range of both isotope fractions in rainwater, fertilizer, terrestrial organic matter and sewage (Li et al., 2010); (c) comparison of DIN yield among different tropical rivers on a global scale; (d) annual precipitation curve derived from Müller et al. (2016) in Sarawak and precipitation in the sampling months during 2016 and 2017 , measured at Sibu station. The figure also shows the Ocean Niño Index in 2016 and 2017. Clearly, in the beginning of 2016, an El Niño event occurred because the index was much higher than the threshold (red dash line: 0.5). Afterwards, two La Niña events were observed (lower than the threshold, highlighted by the blue dash line); (e) and (f) are comparisons among offsets ( $\Delta$ in the figure) for $\mathrm{NO}_{3}^{-}$, $\mathrm{NH}_{4}^{+}$and $\mathrm{DON}$ concentrations in the Lassa branch. The arrows outlined in the figure highlight the possible reaction pathways according to the variations in the offsets.

served from January to June 2016, and the Niño 3.4 Index reached 2.5 (threshold 0.5). Subsequently, La Niña events occurred and introduced stronger precipitations in Malaysia (Fig. 7d). Consequently, the weather in September 2017 was comparably "wetter" than the dry season in August 2016. Reichman et al. (1966) observed that $\mathrm{NH}_{4}^{+}$concentrations in the tested soils decreased after $10 \mathrm{~d}$ incubation at high moisture content. Hopmans et al. (1980) found that the $\mathrm{NH}_{4}^{+}$ concentration in the culture soils at $20 \%$ moisture content was markedly higher than the levels from the $30 \%$ and $35 \%$ moisture content groups. Abera et al. (2012) also revealed a significant reduction in the extractable $\mathrm{NH}_{4}^{+}$content in tropical soils when precipitations enhanced. They addressed the possible reason for the decrease in ammonification intensity being the enhanced moisture in soils, because high moisture could significantly restrain the aeration in peat and tropical soils and further lead to a depletion of oxygen (Daniels et al., 2012). A similar phenomenon might also occur in the Rajang watershed; the $\mathrm{NH}_{4}^{+}$production in the soils likely decreased in September 2017. Concurrently, strong precipitations enhanced river water volume that caused solute dilution. Adding these together, the decline of $\mathrm{NH}_{4}^{+}$concentration in the Rajang water was found. Such variation reflects the dynamic linkage between global climate events and local $\mathrm{N}$ storage.

\section{2 $\mathrm{N}$ transformations in the estuary}

In August 2016, concentrations of $\mathrm{NO}_{3}^{-}, \mathrm{NO}_{2}^{-}$and $\mathrm{NH}_{4}^{+}$ in the estuary mixing zone were higher than levels in the river water and the coastal seawater. This concentration increase generally results from (1) a direct input from tributary streams or porewater exchange and (2) $\mathrm{N}$ transformations. In the Rajang delta, there are several small streams (Fig. 1), continuously adding solutes into the estuary water (Staub et al., 2000; Gastaldo, 2010). Compared with the Rajang, these streams were not the major surface flows in Sarawak (Sa'adi et al., 2017), due to small discharge rates. The solutes from these small loadings can be rapidly diluted in the estuary (Allen, 1982). In addition, the carbon content $\left(p \mathrm{CO}_{2}\right)$ and dissolved organic carbon during the same survey did not show significant peaks in the outlet of these streams (Martin et al., 2018; Müller-Dum et al., 2019). Consequently, the influence introduced from these streams might be minor. Precipitations, adding solutes on a regional scale, could enhance $\mathrm{NH}_{4}^{+}$concentrations in the river water but only within a small temporal scale (Fig. 8a). Alternatively, exchanges between 
(a)
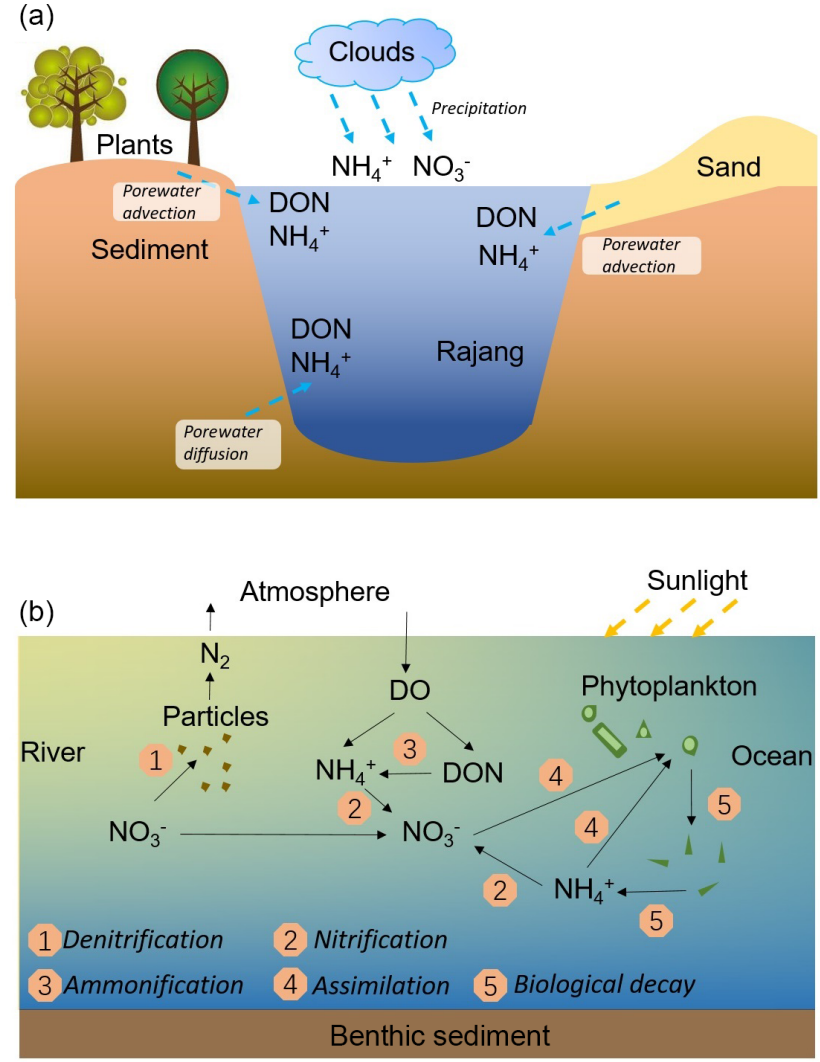

Figure 8. Sketch of the $\mathrm{N}$ input pathways in the Rajang estuary (a) and $\mathrm{N}$ reactions during the mixing between the river water and the coastal ocean water obtained in the current research (b).

pore water in both cohesive and sandy sediments and surface water can add DIN in river water on a regional scale due to large contact areas (Fig. 8a). In coastal zones, this exchange can be driven by tidal pumping, wave actions and density difference (Santos et al., 2012a). In particular, during flooding tide, the tidal sediment marsh was flushed by the estuary water. The overlying water seeped into the sediment along the conduits created by crabs and worms, or plant roots. During ebbing tide, pore water slowly drains and adds solutes in the receiving water (Santos et al., 2012b; Tait et al., 2016). In the current research, $\mathrm{NH}_{4}^{+}$concentrations in all porewater samples were significantly higher than the level found in the estuary water. Coupled with the macro-meso tides in the Rajang estuary, the magnitude of $\mathrm{NH}_{4}^{+}$flux from pore water to the Rajang might be great, as outlined in Fig. 8a, likely to be the main reason for the concentration elevation. Moreover, the diffusion from the benthic sediment to the overlying water also increases $\mathrm{NH}_{4}^{+}$concentrations (Fig. 8a). Notably, low $\mathrm{NO}_{3}^{-}$levels were found in porewater samples, suggesting that the direct effect on the river water $\mathrm{NO}_{3}^{-}$concentration and its isotope fractions was limited.

$\mathrm{N}$ transformations, including ammonification, nitrification, and DNRA (Burgin and Hamilton, 2007), may also markedly contribute to the enhancement of $\mathrm{NH}_{4}^{+} / \mathrm{NO}_{3}^{-}$concentration. Besides $\mathrm{N}$ fixation, ammonification is the only reaction that increases the total DIN concentration, which is coupled with the decomposition of PN and/or DON. In August 2016, the undersaturated DO and high values of OUD were obtained in the mixing zone, suggesting the occurrence of active aerobic respiration on the basis of organic matter decomposition. Concurrently, the abundant SPM in the estuary water was observed, providing a significant amount of PN (Figs. 2 and 7a). However, the PN concentration was relatively conservative in the mixing zone and the $\delta^{15} \mathrm{~N}-\mathrm{PN}$ variation was limited (Fig. S6). Consequently, PN may not be involved in the biogeochemical reaction, and hence it was not the major reactant for the ammonification. Instead, DON, especially the reactive portions, can serve as an active reactant (Brandes et al., 2007). In the mixing experiment, a reduction in the DON concentration was observed, compared to the conservative mixing, which confirms the biogeochemical activity. In the Rajang estuary, despite the injection from sediment pore water (Fig. 8a), net DON consumptions were obtained. DON may be continuously transformed to $\mathrm{NH}_{4}^{+}$ via mineralization and subsequent ammonification (Fig. 8b). Photo-degradation in tropical rivers also accelerates the DON decomposition and benefits accumulation of $\mathrm{NH}_{4}^{+}$in the river water (Martin et al., 2018). In the Lassa branch, a clear DON consumption and the possibility of the occurrence of ammonification was obtained (Fig. 7e and f).

The elevation in the concentrations of $\mathrm{NO}_{2}^{-}$and $\mathrm{NO}_{3}^{-}$was attributed to nitrification, relying on the mineralized $\mathrm{NH}_{4}^{+}$ and porewater-derived $\mathrm{NH}_{4}^{+}$(Fig. 8b). In February 2017, coupled with $\mathrm{NO}_{3}^{-}$concentration increases, declines in $\delta^{15} \mathrm{~N}-\mathrm{NO}_{3}^{-}$and $\delta^{18} \mathrm{O}-\mathrm{NO}_{3}^{-}$were found, which reinforced the statement for the occurrence of nitrification (Fig. 8b). Notably, the enhancement in DIN species varied between tributaries. Compared with the Lassa-Paloh and Rajang tributaries, the distribution of $\mathrm{NO}_{2}^{-}$and $\mathrm{NO}_{3}^{-}$in the Igan tributary during the mixing tended to be conservative and $f$ values were comparatively small (Table S1 in the Supplement), while the $\mathrm{NH}_{4}^{+}$concentration remained high during the mixing. In addition, the OUD in the Igan channel was relatively low in comparison to other tributaries. It could be deduced that the porewater exchange process during the mixing still occurred, while the nitrification intensity in the Igan tributary was relatively weak, which likely results from the significant difference in hydrologic environments. In particular, the Igan channel was the main freshwater outlet because of the comparatively small tidal amplitude but high discharge rate (Jakhrani et al., 2013). The large freshwater plume pushed the mixing zone towards the coastal ocean (Fig. 2). Consequently, the brackish water could be rapidly diluted by the seawater, leading to a short residence time for the mixing. By contrast, the mixing in other river tributaries occurred in the river channels, leading to a slow dilution and a long residence time for the brackish water. The difference in the water residence time likely created the varied reaction intensity (Zar- 
netske et al., 2011). In the light of the reactions between the Lassa and Rajang tributaries, the difference in the reaction pattern (addition) and intensity ( $f$ value) was small, although the proportion of peatland coverage varied due to deforestation (Fig. 1). In the same estuary, Müller-Dum et al. (2019) also reported a limited difference in $\mathrm{CO}_{2}$ emissions between the peat and non-peat areas. Such a pattern may relate to the temporal scale. In particular, the peatland was the product of 6000 -year deposition as aforementioned. The regional deforestation in the estuary occurred in the last 15 years (Miettinen et al., 2016), indicating that the disturbance has not been developed into deep sediments. The influence may not reach a significant level. However, disturbances from the shrinkage of peatland may be enhanced in the future.

The distribution of DIN species and related isotopes in the mixing zone between cruises was also observed, indicating the seasonal variability. In February 2017, the wet season in the Sarawak (Müller et al., 2015), productions of $\mathrm{NO}_{3}^{-}$ and $\mathrm{NO}_{2}^{-}$during the mixing were mild compared to $\mathrm{Au}-$ gust 2016. Accordingly, declines in the magnitude of $f$ were observed, suggesting a weak nitrification intensity. Decreases in the residence time for the brackish water column due to the high river discharge can be the first reason. The second factor that influences the generation of $\mathrm{NO}_{3}^{-}$and $\mathrm{NO}_{2}^{-}$in the estuary water might be SPM-related biogeochemical reactions because suspended particles can be versatile. On the one hand, the $\mathrm{N}$ content on the particle could be released into the water via decomposition (Brandes et al., 2007), subsequently increasing DIN concentration. On the other hand, the suspended particles could provide a large number of anoxic micro-niches for denitrifiers coupled with the oxic degradation (Jia et al., 2016). Together with sediment denitrification, the $\mathrm{NO}_{3}^{-}$removal in the estuary could occur. Consequently, the addition or removal (two possibilities) for $\mathrm{NO}_{3}^{-}$content in estuary water likely depends on the reaction capability of these two controversial pathways.

In the Rajang estuary, the PN content in SPM frequently ranged from $0.1 \%$ to $0.3 \%$, mainly terrestrial-derived solids because of the low concentration of chlorophyll (Martin et al., 2018), smaller than other tropical rivers located in adjacent regions, e.g., the Wonokromo River $(0.5 \%)$ and the Rorong River $(0.85 \%)$ in Indonesia (Jennerjahn et al., 2004) and the Godavari River in India (0.36\%; Gupta et al., 1997). In the mixing experiment, small differences in DON concentration between groups were found, indicating that the decomposition of PN was weak. The oxic consumption of these particles in the upper stream might be the reason for the low reactivity for particles in the degradation potential. Therefore, the presence of high concentrations of PN cannot enhance $\mathrm{NO}_{3}^{-}$addition. Alternatively, the denitrification capability evoked by the SPM can be significant. In the Rajang estuary, suspended particles were enriched in trace metals, such as Fe and Mn (Staub et al., 2000), which potentially accelerates the $\mathrm{NO}_{3}^{-}$removal process by serving as an electron donor or catalyzer (Burgin and Hamilton, 2007). Fur- thermore, in estuaries, the presence of flocculation and adsorption attracts metal ions on the surface of suspended particles, enhancing the denitrification potential. In the mixing experiment, the presence of suspended particles markedly decreased levels of $\mathrm{NO}_{3}^{-}$and $\mathrm{NO}_{2}^{-}$regardless of salinity when compared to the particle-removed group. Additionally, both $\delta^{15} \mathrm{~N}-\mathrm{NO}_{3}^{-}$and $\delta^{18} \mathrm{O}-\mathrm{NO}_{3}^{-}$markedly increased, confirming the presence of denitrification. Moreover, the $\mathrm{NH}_{4}^{+}$concentration during the mixing was conservatively distributed, indicating anammox, which utilizes both $\mathrm{NH}_{4}^{+}$and $\mathrm{NO}_{3}^{-}$, may not be the dominant pathway for $\mathrm{NO}_{2+3}^{-}$removal.

In September 2017, the end of the dry season according to historical records, the DIN distribution trend was markedly different from the pattern from August 2016. Specifically, the generation of $\mathrm{NO}_{3}^{-}$and $\mathrm{NO}_{2}^{-}$was weaker than the pattern in August. For example, the $f$ value was significantly smaller (Table S1) and the $\mathrm{NO}_{3}^{-}$concentration offsets in three tributaries were markedly lower than these values obtained in August 2016. The variation of both $\delta^{15} \mathrm{~N}-\mathrm{NO}_{3}^{-}$and $\delta^{18} \mathrm{O}-$ $\mathrm{NO}_{3}^{-}$during the mixing process was similar to the trend observed in February 2017. Such a pattern likely results from the increase in the river discharge in September 2017 due to the continuous occurrence of La Niña events, as aforementioned. This observation reinforced that the biogeochemical reactions in the tropical zone are mainly constrained by precipitations (Daniels et al., 2012; Xu et al., 2013), and hence the global climate events markedly influence the $\mathrm{N}$ transformations on a local scale. Moreover, it is worth noticing the co-existence of an $\mathrm{NO}_{3}^{-}$concentration increase and a positive $\delta^{15} \mathrm{~N}-\mathrm{NO}_{3}^{-}$offset in the Rajang branch in September 2017 (Fig. 5). Apart from the bias introduced from the endmember selection, such a distribution indicates an introduction of $\mathrm{NO}_{3}^{-}$from human activities. Compared with the Lassa and Igan tributaries, the Rajang tributary is adjacent to Sirikei (Fig. 1c). Anthropogenic activities likely introduced ${ }^{15} \mathrm{~N}-\mathrm{NO}_{3}^{-}$-enriched water, i.e., wastewater or sewage, into the Rajang (Fig. 7b), along several streams. In the future, coupled with population increases in the Rajang watershed, $\mathrm{NO}_{3}^{-}$with an anthropogenic signature may increase in the Rajang delta, which should receive more attention.

\subsection{DIN fluxes and implications}

After the consumption/addition in estuaries, DIN injects into coastal oceans. As outlined in Table S1, the magnitude of $\mathrm{NH}_{4}^{+}$fluxes ranged from 4.57 to $24.7 \mathrm{t} \mathrm{N} \mathrm{d}^{-1}$ and the magnitude of $\mathrm{NO}_{3}^{-}$fluxes peaked at $82.4 \mathrm{t} \mathrm{N} \mathrm{d}^{-1}$. The DIN loading was $77.2 \mathrm{t} \mathrm{N} \mathrm{d}^{-1}$ in the dry season and $101.5 \mathrm{t} \mathrm{N} \mathrm{d}^{-1}$ in the wet season. On a global scale, the DIN delivered from the Rajang to the coastal ocean is relatively minor (Table 2). For the rivers around the South China Sea, the magnitude of Rajang-borne DIN fluxes was less than $1 / 10$ of the DIN loading from the Mekong River and similar to $1 / 6$ of the DIN from the Pearl River. The terrestrial $\mathrm{NO}_{3}^{-}$and $\mathrm{NO}_{2}^{-}$ were rapidly removed in the coastal ocean. Coupled with 
concentration decreases, $\delta^{15} \mathrm{~N}-\mathrm{NO}_{3}^{-}$and $\delta^{18} \mathrm{O}-\mathrm{NO}_{3}^{-}$rapidly increased. In addition, the offset between $\delta^{15} \mathrm{~N}-\mathrm{NO}_{3}^{-}$and $\delta^{18} \mathrm{O}_{-} \mathrm{NO}_{3}^{-}$was closely correlated (Fig. 5). Therefore, the decline in $\mathrm{NO}_{3}^{-}$concentration resulted from the consumption of primary producers (Granger et al., 2010). Along the Sarawak coasts, there are abundant tropical coral reefs and fish resources (Hamli et al., 2012; Praveena et al., 2012; Arai, 2015), relying on phytoplankton and seagrass. The input of DIN likely sustained the growth of primary producers and maintained ecosystem functions. Currently, the riverine DIN input is mild, which did not markedly change the stoichiometry in coastal water. The dominant phytoplankton group was diatom (Saifullah et al., 2014), and harmful algae blooms were not recorded in the Sarawak coasts. In addition, the fishery industry is flourishing and plays an important role in the local economy (Ikhwanuddin et al., 2011; Hamli et al., 2012). However, the Rajang estuary is subject to increasing human pressures, especially from agricultural fields, fallow shrubland and industrial plantations (Ting and Rose, 2014; Miettinen et al., 2016). Logging and oil palm plantations have resulted in peatland deforestation, and the scale is enlarging (Miettinen et al., 2016). It has increased suspended particle concentration and accelerates erosion of terrestrial organic matter (Ling et al., 2017), indicating that a long-term influence derived from human transformations should be noticed in future studies.

\section{Conclusions}

The DIN concentration in the river water varied between seasons in the Rajang, mainly resulting from the decomposition of terrestrial organic matter. Strong precipitations, induced by La Niña events, might inhibit soil ammonification in the watershed and hence decreased $\mathrm{NH}_{4}$ concentrations in the river water in September 2017. This indicates a causal chain between climate events and $\mathrm{N}$ cycling in tropical soils and rivers. In the estuary, porewater exchanges and decomposition of terrestrial DON increased $\mathrm{NH}_{4}^{+}$concentration and nitrification increased $\mathrm{NO}_{2}^{-}$and $\mathrm{NO}_{3}^{-}$levels, while denitrification likely occurred on particle surfaces. Since nitrification exceeded denitrification, $\mathrm{NO}_{3}^{-}$addition was observed in the mixing zone. The riverine DIN loading to the coastal ocean ranged from $77.2 \mathrm{t} \mathrm{N} \mathrm{d}^{-1}$ in the dry season to $101.5 \mathrm{t} \mathrm{N} \mathrm{d}^{-1}$ in the wet season. Due to the mild concentration in the river water, Rajang-borne DIN likely adds positive effects to the coastal system, sustaining the primary productivity in the coastal zone. Currently, the Rajang estuary is subject to intensive human developments, which may add significant impacts on DIN transport and transformations in the future. In addition, the reaction trends and $\mathrm{N}$ solute distributions obtained from the present study may benefit global $\mathrm{N}$ budget estimations.
Data availability. The datasets used and/or analyzed in the present study are available from the corresponding author on reasonable request.

Supplement. The supplement related to this article is available online at: https://doi.org/10.5194/bg-16-2821-2019-supplement.

Author contributions. JZ, MM, YW and SJ designed the study. JZ, EA, FJ and MM performed the sample collection and in situ measurements for the first cruise. SJ, KZ, AM, EA, FJ and MM performed samplings and in situ measurements for the second and third cruises. SJ, JJ, GZ, YW, KZ, and TR completed laboratory analyses. All the co-authors equally participated in the interpretation and discussion of the results. SJ prepared the manuscript with suggestions from all the co-authors.

Competing interests. The authors declare that they have no conflict of interest.

Special issue statement. This article is part of the special issue "Biogeochemical processes in highly dynamic peat-draining rivers and estuaries in Borneo". It is not associated with a conference.

Acknowledgements. The authors would like to thank the Sarawak Forestry Department and Sarawak Biodiversity Centre for permission to conduct collaborative research in Sarawak waters under permit numbers NPW.907.4.4(Jld.14)-161, Park Permit No WL83/2017, and SBC-RA-0097-MM. Lukas Chin and the "SeaWonder" crew are acknowledged for their support during the cruises. Technical support by Patrick Martin and Gonzalo Carrasco at Nanyang Technological University during the cruises and Lijun Qu, Wanwan Cao, Xiaohui Zhang, and Xunchi Zhu at East China Normal University in the laboratory analyses is gratefully acknowledged. We also appreciate the great assistance from Zhiming $\mathrm{Yu}$ at the Institute of Oceanology, Chinese Academy of Sciences, for the stable isotope analyses.

Financial support. This research has been supported by the Newton-Ungku Omar Fund (grant no. NE/P020283/1), the China Postdoctoral Science Foundation (grant no. 2018M630416), the MOHE FRGS 15 Grant (grant no. FRGS/1/2015/WAB08/SWIN/02/1), the Ministry of Education of the People's Republic of China (grant no. B08022), and the State Key Laboratory of Estuarine and Coastal Research (grant nos. SKLEC-KF201610 and 2017RCDW04).

Review statement. This paper was edited by Tim Jennerjahn and reviewed by Zhiming Yu and one anonymous referee. 


\section{References}

Abera, G., Wolde-meskel, E., Beyene, S., and Bakken, L. R.: Nitrogen mineralization dynamics under different moisture regimes in tropical soils, Int. J. Soil S., 7, 132-145, 2012.

Allen, C. M.: Numerical simulation of contaminant dispersion in estuary flow, P. Roy. Soc. Lond. A Mat., 381, 179-194, 1982.

Arai, T.: Diversity and conservation of coral reef fishes in the Malaysian South China Sea, Rev. Fish Biol. Fisher., 25, 85-101, 2015.

Barbier, E. B., Hacker, S. D., Kennedy, C., Koch, E. W., Stier, A. C., and Silliman, B. R.: The value of estuarine and coastal ecosystem services, Ecol. Monogr., 81, 169-193, 2011.

Baum, A. and Rixen, T.: Dissolved inorganic nitrogen and phosphate in the human affected blackwater river Siak, central Sumatra, Indonesia, Asian J. Water Environ. Pollut., 11, 13-24, 2014.

Battaglin, W., Aulenbach, B., Vecchia, A., and Buxton, H.: Changes in Streamflow and the Flux of Nutrients in the MississippiAtchafalaya River Basin, USA, 1980-2007, USGS Scientific Investigation Report 2009-5164, 2010.

Bouillon, S., Abril, G., Borges, A. V., Dehairs, F., Govers, G., Hughes, H. J., Merckx, R., Meysman, F. J. R., Nyunja, J., Osburn, C., and Middelburg, J. J.: Distribution, origin and cycling of carbon in the Tana River (Kenya): a dry season basin-scale survey from headwaters to the delta, Biogeosciences, 6, 2475-2493, https://doi.org/10.5194/bg-6-2475-2009, 2009.

Brandes, J. A., Devol, A. H., and Deutsch, C.: New Developments in the Marine Nitrogen Cycle, ChemInform, 38, 577-589, 2007.

Burgin, A. J. and Hamilton, S. K.: Have we overemphasized the role of denitrification in aquatic ecosystems? A review of nitrate removal pathways, Front. Ecol. Environ. 5, 89-96, 2007.

Cai, P., Shi, X., Hong, Q., Li, Q., Liu, L., Guo, X., and Dai, M.: Using ${ }^{224} \mathrm{Ra} /{ }^{228} \mathrm{Th}$ disequilibrium to quantify benthic fluxes of dissolved inorganic carbon and nutrients into the Pearl River Estuary, Geochim. Cosmochim. Ac., 170, 188-203, 2015.

Canfield, D. E., Glazer, A. N., and Falkowski, P. G.: The Evolution and Future of Earth's Nitrogen Cycle, Science, 330, 192-196, 2010.

Casciotti, K. L. and McIlvin, M. R.: Isotopic analyses of nitrate and nitrite from reference mixtures and application to Eastern Tropical North Pacific waters, Mar. Chem., 107, 184-201, 2007.

Daniels, S. M., Evans, M. G., Agnew, C. T., and Allott, T. E. H.: Ammonium release from a blanket peatland into headwater stream systems, Environ. Pollut., 163, 261-272, 2012

Ebina, J., Tsutsui, T., and Shirai, T.: Simultaneous determination of total nitrogen and total phosphorus in water using peroxodisulfate oxidation, Water Res., 17, 1721-1726, 1983.

Falco, S., Niencheski, L. F., Rodilla, M., Romero, I., González, d. R. J., Sierra, J. P., and Mösso, C.: Nutrient flux and budget in the Ebro estuary. Estuar. Coast Shelf S., 87, 92-102, 2010.

Galloway, J. N., Dentener, F. J., Capone, D. G., Boyer, E. W., Howarth, R. W., Seitzinger, S. P., Asner, G. P., Cleveland, C. C., Green, P. A., and Holland, E. A.: Nitrogen cycles: past, present, and future, Biogeochemistry, 70, 153-226, 2004.

Gastaldo, R. A.: Peat or no peat: Why do the Rajang and Mahakam Deltas differ?, Int. J. Coal Geol., 83, 162-172, 2010.

Goñi-Urriza, M. S., Point, D., Amouroux, D., Guyoneaud, R., Donard, O. F. X., Caumette, P., and Duran, R.: Bacterial community structure along the Adour estuary (French Atlantic coast): influence of salinity gradient versus metal contamination, Aquat. Microb. Ecol., 49, 47-56, 2007.

Granger, J., Sigman, D. M., Rohde, M. M., Maldonado, M. T., and Tortell, P. D.: $\mathrm{N}$ and $\mathrm{O}$ isotope effects during nitrate assimilation by unicellular prokaryotic and eukaryotic plankton cultures, Geochim. Cosmochim. Ac., 74, 1030-1040, 2010.

Grasshoff, K., Kremling, K., and Ehrhardt, M.: Chapter 10. Determination of nutrients, Wiley-VCH Verlag GmbH, Weinheim, Germany, 2007.

Gruber, N. and Galloway, J. N.: An Earth-system perspective of the global nitrogen cycle, Nature, 451, 293-296, 2008.

Gupta, L. P., Subramanian, V., and Ittekkot, V.: Biogeochemistry of particulate organic matter transported by the Godavari River, India, Biogeochemistry, 38, 103-128, 1997.

Hamli, H., Idris, M. H., Hena, M. K. A., and Wong, S. K.: Taxonomic Study of Edible Bivalve from Selected Division of Sarawak, Malaysia, Int. J. Zool. Res., 8, 52-58, 2012.

Holmes, R. M., McClelland, J. W., Peterson, B. J., Tank, S. E., Bulygina, E., Eglinton, T. I., Gordeev, V. V., Gurtovaya, T. Y., Raymond, P. A., Repeta, D. J., Staples, R., Strigel, R. G., Zhulidov, A. V., and Zimov, S. A.: Seasonal and Annual Fluxes of Nutrients and Organic Matter from Large Rivers to the Arctic Ocean and Surrounding Seas, Estuar. Coast, 35, 369-382, 2012.

Hopmans, P., Flinn, D. W., and Farrell, P. W.: Nitrogen mineralization in a sandy soil under native eucalypt forest and exotic pine plantations in relation to moisture content, Commun. Soil Sci. Plan., 11, 71-79, 1980.

Iida, T., Inkhamseng, S., Yoshida, K., and Ito, S.: Seasonal Variation in Nitrogen and Phosphorus Concentrations in the Mekong River at Vientiane, Journal of Japan Society of Hydrology \& Water Resources, 20, 226-234, 2007.

Ikhwanuddin, M., Azmie, G., Juariah, H. M., Zakaria, M. Z., and Ambak, M. A.: Biological information and population features of mud crab, genus Scylla from mangrove areas of Sarawak, Malaysia, Fish Res., 108, 299-306, 2011.

Jakhrani, A. Q., Rigit, A. R. H. and Samo, S. R.: Estimiation of tidal stream energy resources at Sarawak coastline and their potential impact on environment, Australian Journal of Basic and Applied Sciences, 7, 503-514, 2013.

Jennerjahn, T. C., Ittekkota, V., Adib, S., Nugrohob, S. P., Sudianab, N., Yusmalb, A., and Gaye-Haakec, P.: Biogeochemistry of a tropical river affected by human activities in its catchment: Brantas River estuary and coastal waters of Madura Strait, Java, Indonesia, Estuar. Coast Shelf S., 60, 503-514, 2004.

Jia, Z., Liu, T., Xia, X., and Xia, N.: Effect of particle size and composition of suspended sediment on denitrification in river water, Sci. Total Environ., 541, 934-940, 2016.

Kuo, N. W., Jien, S. H., Hong, N. M., Chen, Y. T., and Lee, T. Y.: Contribution of urban runoff in Taipei metropolitan area to dissolved inorganic nitrogen export in the Danshui River, Taiwan, Environ. Sci. Pollut. R., 24, 1-13, 2017.

Lam, M. K., Tan, K. T., Lee, K. T., and Mohamed, A. R.: Malaysian palm oil: Surviving the food versus fuel dispute for a sustainable future, Renew. Sust. Energ. Rev., 13, 1456-1464, 2009.

Li, R., Liu, S., Zhang, G., Ren, J., and Zhang, J.: Biogeochemistry of nutrients in an estuary affected by human activities: The Wanquan River estuary, eastern Hainan Island, China, Cont. Shelf Res., 57, 18-31, 2013. 
Li, S. L., Liu, C. Q., Li, J., Liu, X., Chetelat, B., Wang, B., and Wang, F.: Assessment of the sources of nitrate in the Changjiang River, China using a nitrogen and oxygen isotopic approach, Environ. Sci. Technol., 44, 1573-1578, 2010.

Liljeström, I., Kummu, M., and Varis, O.: Nutrient Balance Assessment in the Mekong Basin: Nitrogen and Phosphorus Dynamics in a Catchment Scale, Int. J. Water Resour. D., 28, 373-391, 2012.

Ling, T. Y., Soo, C. L., Phan, T. P., Lee, N., Sim, S. F., and Grinang, J.: Assessment of the Water Quality of Batang Rajang at Pelagus Area, Sarawak, Malaysia, Sains Malays., 46, 401-411, 2017.

Liss, P. S.: Conservative and non-conservative behavior of dissolved constituents during estuarine mixing, Estuarine Chemistry, 93130, London Academic Press, London, UK, 1976.

Martin, P., Cherukuru, N., Tan, A. S. Y., Sanwlani, N., Mujahid, A., and Müller, M.: Distribution and cycling of terrigenous dissolved organic carbon in peatland-draining rivers and coastal waters of Sarawak, Borneo, Biogeosciences, 15, 6847-6865, https://doi.org/10.5194/bg-15-6847-2018, 2018.

Melling, L., Hatano, R., and Goh, K. J.: Nitrous oxide emissions from three ecosystems in tropical peatland of Sarawak, Malaysia, Soil Sci. Plant Nutr., 53, 792-805, 2007.

Middelburg, J. J. and Nieuwenhuize, J.: Nitrogen Isotope Tracing of Dissolved Inorganic Nitrogen Behaviour in Tidal Estuaries, Estuar. Coast Shelf S., 53, 385-391, 2001.

Miettinen, J., Shi, C., and Liew, S. C.: Land cover distribution in the peatlands of Peninsular Malaysia, Sumatra and Borneo in 2015 with changes since 1990, Glob. Ecol. Conserv., 6, 67-78, 2016.

Müller, D., Warneke, T., Rixen, T., Müller, M., Jamahari, S., Denis, N., Mujahid, A., and Notholt, J.: Lateral carbon fluxes and $\mathrm{CO}_{2}$ outgassing from a tropical peat-draining river, Biogeosciences, 12, 5967-5979, https://doi.org/10.5194/bg-12-5967-2015, 2015.

Müller, D., Bange, H. W., Warneke, T., Rixen, T., Müller, M., Mujahid, A., and Notholt, J.: Nitrous oxide and methane in two tropical estuaries in a peat-dominated region of northwestern Borneo, Biogeosciences, 13, 2415-2428, https://doi.org/10.5194/bg-132415-2016, 2016.

Müller-Dum, D., Warneke, T., Rixen, T., Müller, M., Baum, A., Christodoulou, A., Oakes, J., Eyre, B. D., and Notholt, J.: Impact of peatlands on carbon dioxide $\left(\mathrm{CO}_{2}\right)$ emissions from the Rajang River and Estuary, Malaysia, Biogeosciences, 16, 17-32, https://doi.org/10.5194/bg-16-17-2019, 2019.

Praveena, S. M., Siraj, S. S., and Aris, A. Z.: Coral reefs studies and threats in Malaysia: a mini review, Rev. Environ. Sci. Bio., 11, 27-39, 2012.

Reichman, G. A., Grunes, D. L., and Viets Jr., F. G.: Effect of soil moisture on ammonification and nitrification in two northern plains soils, Soil Sci. Soc. Am. Pro., 30, 363-366, 1966.

Richardson, D. M., Holmes, P. M., Esler, K. J., Galatowitsch, S. M., Stromberg, J. C., Kirkman, S. P., Pyšek, P., and Hobbs, R. J.: Riparian vegetation: degradation, alien plant invasions, and restoration prospects, Divers. Distrib., 13, 126-139, 2007.

Sa'adi, Z., Shahid, S., Ismail, T., Chung, E. S., and Wang, X. J.: Distributional changes in rainfall and river flow in Sarawak, Malaysia, Asia-Pac, J. Atmos. Sci., 53, 1-12, 2017.

Saifullah, A. S. M., Abu, H. M. K., Idris, M. H., Halimah, A. R., and Johan, I.: Diversity of phytoplankton from mangrove estuaries of Sarawak, Malaysia, J. Biol. Sci., 14, 361-369, 2014.
Salam, M. N. A. and Gopinath, N.: Riverine fish and fisheries in Malaysia: An ignored resource, Aquat. Ecosyst. Health, 9, 159164, 2006.

Sale, P. F., Agardy, T., Ainsworth, C. H., Feist, B. E., Bell, J. D., Christie, P., Hoegh-Guldberg, O., Mumby, P. J., Feary, D. A., and Saunders, M. I.: Transforming management of tropical coastal seas to cope with challenges of the 21 st century, Mar. Pollut. Bull., 85, 8-23, 2014.

Santos, I. R., Eyre, B. D., and Huettel, M.: The driving forces of porewater and groundwater flow in permeable coastal sediments: A review, Estuar. Coast Shelf S., 98, 1-15, 2012a.

Santos, I. R., Cook, P. L. M., Rogers, L., Weys, Jd., and Eyre, B. D.: The "salt wedge pump": Convection-driven pore-water exchange as a source of dissolved organic and inorganic carbon and nitrogen to an estuary, Limnol. Oceanogr., 57, 1415-1426, $2012 \mathrm{~b}$.

Santos, M. L., Muniz, K., Barrosneto, B., and Araujo, M.: Nutrient and phytoplankton biomass in the Amazon River shelf waters, Anais Da Academia Brasileira De Ciências, 80, 703-717, 2008.

Sebilo, M., Billen, G., Mayer, B., Billiou, D., Grably, M., Garnier, J., and Mariotti, A.: Assessing Nitrification and Denitrification in the Seine River and Estuary Using Chemical and Isotopic Techniques, Ecosystems, 9, 564-577, 2006.

Seitzinger, S. P., Kroeze, C., Bouwman, A. F., Caraco, N., Dentener, F., and Styles, R. V.: Global patterns of dissolved inorganic and particulate nitrogen inputs to coastal systems: Recent conditions and future projections, Estuaries, 25, 640-655, 2002.

Selemani, J. R., Zhang, J., Muzuka, A. N. N., Njau, K. N., Zhang, G., Mzuza, M. K., and Maggid, A.: Nutrients' distribution and their impact on Pangani River Basin's ecosystem - Tanzania, Environ. Technol., 39, 702-716, 2017.

Sigman, D. M., Casciotti, K. L., Andreani, M., Barford, C., Galanter, M., and Böhlke, J. K.: A bacterial method for the nitrogen isotopic analysis of nitrate in seawater and freshwater, Anal. Chem., 73, 4145-4153, 2001.

Spietz, R. L., Williams, C. M., Rocap, G., and Horner-Devine, M. C.: A Dissolved Oxygen Threshold for Shifts in Bacterial Community Structure in a Seasonally Hypoxic Estuary, Plos One, 10, e0135731, https://doi.org/10.1371/journal.pone.0135731, 2015.

Spiteri, C., Cappellen, P. V., and Regnier, P.: Surface complexation effects on phosphate adsorption to ferric iron oxyhydroxides along $\mathrm{pH}$ and salinity gradients in estuaries and coastal aquifers, Geochim. Cosmochim. Ac., 72, 3431-3445, 2008.

Staub, J. R., Among, H. L., and Gastaldo, R. A.: Seasonal sediment transport and deposition in the Rajang River delta, Sarawak, East Malaysia, Sediment Geol., 133, 249-264, 2000.

Tait, D. R., Maher, D. T., Macklin, P. A., and Santos, I. R.: Mangrove porewater exchange across a latitudinal gradient, Geophys. Res. Lett., 43, 3334-3341, 2016.

Tarmizi, A. M. and Mohd, T. D.: Nutrient demands of Tenera Oil Palm planted on inland soils of Malaysia, J. Oil Palm Res., 18, 204-209, 2006.

Ting, S. H. and Rose, L.: Ethnic Language Use and Ethnic Identity for Sarawak Indigenous Groups in Malaysia, Oceanic Linguist., 53, 92-109, 2014.

Tran, V. T.: The middle-income trap: Issues for members of the association of Southeast Asian nations, ADBI Working Paper 421, Asian Development Bank Institute, Manila, 2013.

Vitousek, P. M., Aber, J. D., Howarth, R. W., Likens, G. E., Matson, P. A., Schindler, D. W., Schlesinger, W. H., and Tilman, D. 
G.: Human Alteration of the Global Nitrogen Cycle: Sources and Consequences, Ecol. Appl., 7, 737-750, 1997.

Uddin, M. M., Zafar, M., and Chowdhury, S. R.: Water, salt and nutrient flux through the lower Meghna River estuary, Bangladesh, Indian J. Geo.-Mar. Sci., 43, 280-283, 2014.

Voss, M., Bange, H. W., Dippner, J. W., Middelburg, J. J., Montoya, J. P., and Ward, B.: The marine nitrogen cycle: recent discoveries, uncertainties and the potential relevance of climate change, Philos. T. R. Soc. B, 368, 20130121, https://doi.org/10.1098/rstb.2013.0121, 2013.

Weigand, M. A., Foriel, J., Barnett, B., Oleynik, S., and Sigman, D. M.: Updates to instrumentation and protocols for isotopic analysis of nitrate by the denitrifier method, Rapid Commun. Mass Sp., 30, 1365-1370, 2016.

Wong, W. W., Grace, M. R., Cartwright, I., and Cook, P. L. M.: Sources and fate of nitrate in a groundwater-fed estuary elucidated using stable isotope ratios of nitrogen and oxygen, Limnol. Oceanogr., 59, 1493-1509, 2015.

$\mathrm{Xu}, \mathrm{Y}$., Xu, Z., Cai, Z., and Reverchon, F.: Review of denitrification in tropical and subtropical soils of terrestrial ecosystems, J. Soils Sediments, 13, 699-710, 2013.
Yan, X., Xu, M. N., Wan, X. S., Yang, J. Y. T., Trull, T. W., Dai, M., and Kao, S. J.: Dual Isotope Measurements Reveal Zoning of Nitrate Processing in the Summer Changjiang (Yangtze) River Plume, Geophys. Res. Lett., 44, 12289-12297, 2017.

Yu, H., Yu, Z., Song, X., Cao, X., Yuan, Y., and Lu, G.: Seasonal variations in the nitrogen isotopic composition of dissolved nitrate in the Changjiang River estuary, China, Estuar. Coast Shelf S., 155, 148-155, 2015.

Zarnetske, J. P., Haggerty, R., Wondzell, S. M., and Baker, M. A.: Dynamics of nitrate production and removal as a function of residence time in the hyporheic zone, J. Geophys. Res.-Biogeo., 116, 944-956, 2011.

Zhang, R., John, S. G., Zhang, J., Ren, J., Wu, Y., Zhu, Z., Liu, S., Zhu, X., Marsay, C. M., and Wenger, F.: Transport and reaction of iron and iron stable isotopes in glacial meltwaters on Svalbard near Kongsfjorden: From rivers to estuary to ocean, Earth Planet. Sc. Lett., 424, 201-211, 2015. 